ARTICLE

Received 13 Oct 2016 | Accepted 24 May 2017 | Published 17 Jul $2017 \quad$ DOl: 10.1038/ncomms16066

\title{
Modulation of nongenomic activation of PI3K signalling by tetramerization of $\mathrm{N}$-terminally- cleaved $\mathrm{RXR} \alpha$
}

Liqun Chen ${ }^{1,2,3, \star}$, Alexander E. Aleshin ${ }^{3, \star}$, Gulimiran Alitongbieke, Yuqi Zhou', Xindao Zhang ${ }^{1}$, Xiaohong Ye ${ }^{1}$,

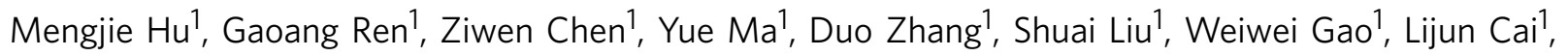
Lingjuan Wu ${ }^{2}$, Zhiping Zeng ${ }^{1}$, Fuquan Jiang ${ }^{1}$, Jie Liu' ${ }^{1}$ Hu Zhou ${ }^{1}$, Gregory Cadwell ${ }^{3}$, Robert C. Liddington ${ }^{3}$, Ying $\mathrm{Su}^{1,3} \&$ Xiao-kun Zhang ${ }^{1,3}$

Retinoid $X$ receptor-alpha ( $R X R \alpha)$ binds to DNA either as homodimers or heterodimers, but it also forms homotetramers whose function is poorly defined. We previously discovered that an $\mathrm{N}$-terminally-cleaved form of $\mathrm{RXR} \alpha(\operatorname{tRXR} \alpha)$, produced in tumour cells, activates phosphoinositide 3-kinase (PI3K) signalling by binding to the p85 $\alpha$ subunit of PI3K and that $\mathrm{K}-80003$, an anti-cancer agent, inhibits this process. Here, we report through crystallographic and biochemical studies that K-80003 binds to and stabilizes tRXR $\alpha$ tetramers via a 'threepronged' combination of canonical and non-canonical mechanisms. K-80003 binding has no effect on tetramerization of $R X R \alpha$, owing to the head-tail interaction that is absent in $t R X R \alpha$. We also identify an LxxLL motif in $p 85 \alpha$, which binds to the coactivator-binding groove on $t R X R \alpha$ and dissociates from $t R X R \alpha$ upon $t R X R \alpha$ tetramerization. These results identify conformational selection as the mechanism for inhibiting the nongenomic action of $\operatorname{tRXR} \alpha$ and provide molecular insights into the development of RXR $\alpha$ cancer therapeutics.

\footnotetext{
${ }^{1}$ School of Pharmaceutical Sciences, Fujian Provincial Key Laboratory of Innovative Drug Target Research, Xiamen University, Xiamen 361102, China. ${ }^{2}$ College of Biological Science and Engineering, Fuzhou University, Fuzhou 350108, China. ${ }^{3}$ Sanford Burnham Prebys Medical Discovery Institute, 10901 , North Torrey Pines Road, La Jolla, California 92037, USA. * These authors contributed equally to this work. Correspondence and requests for materials should be addressed to Y.S. (email: ysu@sbpdiscovery.org) or to X.-k.Z. (email: xzhang@sbpdiscovery.org).
} 
$\mathrm{M}$ any therapeutic target proteins including nuclear receptors exist in equilibrium between different oligomeric states that control their biological functions ${ }^{\mathrm{P}-3}$. Retinoid X receptor $\alpha(\mathrm{RXR} \alpha)$, a member of the nuclear receptor superfamily and a validated drug target, exists in different oligomeric forms that regulate a broad spectrum of cellular processes under both physiological and pathophysiological conditions $^{4-11}$. Like other nuclear receptors, RXR $\alpha$ comprises an intrinsically disordered N-terminal A/B domain with poorly defined functions, a central DNA-binding domain (DBD), and a ligand-binding domain (LBD) in which $\alpha$-helices are arranged around a central hydrophobic ligand-binding pocket (LBP $)^{4-11}$. Helix 12 (H12), at the $\mathrm{C}$ terminus of $\mathrm{RXR} \alpha$, undergoes large movements in response to ligand binding ${ }^{12}$. For example, agonist binding induces $\mathrm{H} 12$ to adopt an active conformation that, together with elements of helices $\mathrm{H} 3$ and $\mathrm{H} 4$, create a groove for binding coactivators that leads to transactivation ${ }^{10,13-16}$. In contrast, in the absence of agonist or in the presence of antagonist, $\mathrm{H} 12$ adopts an inactive conformation that favors the binding of corepressors, which serve to inhibit target gene transcription. Coactivators contain interaction domains with an LxxLL motif (NR box), while corepressors utilize a variant of this motif, L/IxxI/VI (co-repressor NR box, CoRNR) ${ }^{10,13-16}$

In addition to acting as heterodimeric partners of some nuclear receptors ${ }^{4-11,17}, \operatorname{RXR} \alpha$ can form homodimers ${ }^{18}$ that trigger specific signalling pathways ${ }^{19-21}$. A unique property of $\operatorname{RXR} \alpha$ is an auto-repressive mechanism involving homotetramerization, in which a 'dimer-of-dimers' pack in a bottom-to-bottom manner, with $\mathrm{H} 12$ from each monomer invading (and invaded by) a neighbouring domain across the tetramer interface ${ }^{22}$. This pairwise 'exchange of arms' enables each monomer to bind to and occlude the coregulator-binding groove of its neighbour ${ }^{22}$. Some molecules have been shown to promote the auto-repressed state and repress gene transcription ${ }^{23}$. The equilibrium between inactive homotetramers and active homodimers is tightly regulated by ligand binding ${ }^{18,22,24}$. Thus, binding of agonists such as 9-cis-retinoic acid (9-cis-RA) results in dissociation of homotetramers into homodimers, which has been proposed as a regulatory mechanism for $\operatorname{RXR} \alpha$ transactivation ${ }^{22,25}$. However, compounds that act to promote $\mathrm{RXR} \alpha$ homotetramerization remain to be identified and characterized.

Recent advances have revealed important nongenomic functions of $\operatorname{RXR} \alpha$ and its non-canonical modulators ${ }^{7,26-28}$. We previously found that $R X R \alpha$ is abnormally cleaved in many cancer cells, resulting in a truncated $\operatorname{RXR} \alpha(\operatorname{tRXR} \alpha)$ that lacks a portion of its $\mathrm{N}$-terminal $\mathrm{A} / \mathrm{B}$ domain ${ }^{29}$. Unlike the wild-type $\operatorname{RXR} \alpha$, which normally resides in the nucleus, $\operatorname{tRXR} \alpha$ is cytoplasmic, and we showed that it interacts with the $\mathrm{p} 85 \alpha$ regulatory subunit of the phosphatidylinositol 3-kinase (PI3K), a critical player in a wide range of cellular processes including cell growth, proliferation, survival, motility, metabolism, protein synthesis and migration ${ }^{30,31}$. The interaction with $\mathrm{p} 85 \alpha$ promotes PI3K/AKT activation and enhances tumour cell growth, revealing an oncogenic effect of $\operatorname{tRXR} \alpha$ in tumour cells. We also reported that K-80003, a promising anti-cancer agent derived from the non-steroidal anti-inflammatory drug (NSAID) Sulindac, binds to tRXR $\alpha$ and inhibits its interaction with $\mathrm{p} 85 \alpha$ and activation of PI3K signalling 29 . However, the molecular mechanism of this potent inhibition remained to be determined.

Here, we report the crystal structure of $\operatorname{RXR} \alpha$-LBD in complex with K-80003, and the characterization of the role of K-80003mediated $\operatorname{tRXR} \alpha$ tetramerization in regulating its interaction with p $85 \alpha$ and the nongenomic activation of PI3K signalling. Our results reveal a previously unrecognized role of $\operatorname{RXR} \alpha$ tetramers in modulating subcellular localization and nongenomic interaction with cytoplasmic signalling proteins. Moreover, we show that
K-80003 inhibits $\operatorname{tRXR} \alpha$ interaction with $\mathrm{p} 85 \alpha$ by stabilizing a tetrameric form of $\mathrm{tRXR} \alpha$ through a 'three-pronged' mechanism involving both canonical and non-canonical binding. This work opens up new avenues for developing novel $\operatorname{RXR} \alpha$-based therapeutics, by selectively stabilizing a particular oligomeric state.

\section{Results}

Crystal structure of K-80003-bound RXR $\alpha$-LBD. To understand how K-80003 (Supplementary Fig. 1a) modulates the biological activity of $\operatorname{tRXR} \alpha$, we determined the crystal structure of $\mathrm{RXR} \alpha-\mathrm{LBD}$ in complex with $\mathrm{K}-80003$ to a resolution of $2.6 \AA$ (Table 1). We found that the $\mathrm{RXR} \alpha-\mathrm{LBD} / \mathrm{K}-80003$ complex adopts a tetrameric structure, similar to those observed in crystals of apo-RXR $\alpha$ or RXR $\alpha$-LBD/tRA-isomer complex ${ }^{22}$ (Supplementary Fig. 1b), in which two RXR $\alpha$-LBD canonical homodimers (labelled A1/B1 and A2/B2) pack in a bottom-tobottom manner (Fig. 1a) with point group symmetry D2. Besides the canonical dimer interface ${ }^{32}$, there are two symmetry-related interfaces involving subunits $\mathrm{A} 1 / \mathrm{B} 2$ and B1/A2. These 'tetramer' interfaces comprise three sub-regions: parallel packing between symmetry-related $\mathrm{H} 3$ helices; 'end-to-end' packing between $\mathrm{H} 11$ that reduces their length by two helical turns (compared with the agonist-bound structure); and the invasion of each $\mathrm{H} 12$ helix into its apposing domain, where it binds to the coregulator-binding groove, consisting of elements of $\mathrm{H} 3$ and $\mathrm{H} 4$ (Fig. 1a). The apposing domain reciprocates the process in a pairwise 'exchange of C-terminal arms'. An LMEML motif near the C terminus of $\mathrm{H} 12$ binds to the coregulator groove by mimicking the LxxLL/ LxxIL motif of coregulators (Supplementary Fig. 2). The tetramer interfaces create two substantial symmetry-related interfacial cavities that are readily accessible to solvent and small molecules.

Refinement of the structure and careful inspection of difference Fourier maps revealed six molecules of K-80003-bound per tetramer, with three molecules per $\mathrm{A} 1 / \mathrm{B} 2$ or $\mathrm{A} 2 / \mathrm{B} 1$ interfacial cavity (Fig. 1a; Supplementary Fig. 3). This stoichiometry is

Table 1 | Data collection and refinement statistics.

\begin{tabular}{|c|c|}
\hline & RXR $\alpha-L B D / K-80003$ \\
\hline \multicolumn{2}{|l|}{ Data collection } \\
\hline Space group & $P 2_{1}$ \\
\hline \multicolumn{2}{|l|}{ Cell dimensions } \\
\hline$a, b, c(\AA), \beta\left(^{\circ}\right)$ & $46.6,99.4,109.9,99.2$ \\
\hline Resolution $(\AA)$ & $34-2.6(2.7-2.6)^{\star}$ \\
\hline$R_{\text {merge }}$ & $0.080(0.96)$ \\
\hline$|/ \sigma|$ & $6.1(1.2)$ \\
\hline Completeness (\%) & $100(100)$ \\
\hline Redundancy & $3.7(3.5)$ \\
\hline \multicolumn{2}{|l|}{ Refinement } \\
\hline Resolution range $(\AA)$ & $34-2.6$ \\
\hline No. reflections work set $\left(R_{\text {FREE }}\right.$ set) & $30,186(1,341)$ \\
\hline$R_{\text {WORK }} / R_{\text {FREE }}$ & $0.195 / 0.242$ \\
\hline \multicolumn{2}{|l|}{ No. of atoms } \\
\hline Protein & 6,618 \\
\hline Ligands & 194 \\
\hline Water & 134 \\
\hline \multicolumn{2}{|l|}{$B$-factors $\left(\AA^{2}\right)$} \\
\hline Protein & 66.4 \\
\hline Ligands & 85 \\
\hline Water & 53 \\
\hline \multicolumn{2}{|l|}{ R.m.s. deviations } \\
\hline Bond lengths $(\AA)$ & 0.002 \\
\hline Bond angles $\left({ }^{\circ}\right)$ & 0.61 \\
\hline
\end{tabular}


a

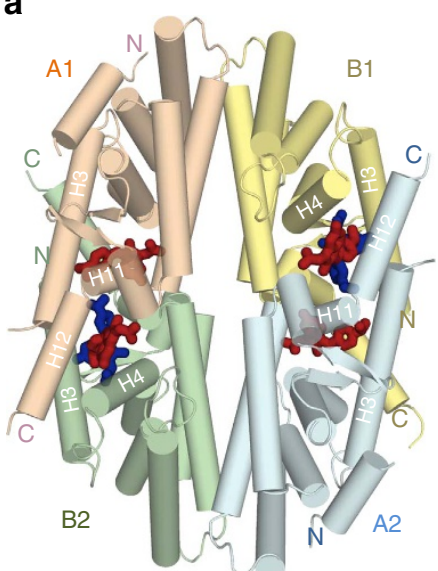

b

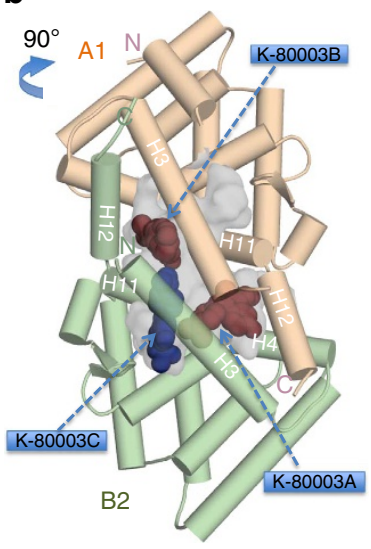

Figure 1 | Crystal structure of the RXR $\alpha$-LBD tetramer in complex with K-80003. (a) The RXR $\alpha-L B D$ tetramer in complex with K-80003. The two biological dimers (A1/B1 and A2/B2) are shown as wheat/yellow and green/cyan cartoons, respectively. The bound K-80003 molecules are shown as brown sticks and blue sticks. Helices contributing to the tetramer interfaces are marked. (b) The orthogonal view showing the hydrophobic void (semitransparent grey) at the interface between the subunits $A 1$ and B2. The smaller pockets and water channels are removed for clarity. $3 \mathrm{~K}-80003$ molecules (K-80003A, B and K-80003C) filling the cavity are shown as blue and brown balls.

consistent with values derived by isothermal titration calorimetry (ITC) (Supplementary Fig. 5a). The $2 \mathrm{~A} 1 / \mathrm{B} 2$ and A2/B1 interfacial cavities are symmetry-related and the three bound molecules in each cavity (K-80003A, K-80003B and K-80003C, respectively, Fig. 1b) appear to play distinct but complementary roles in stabilizing the tetramer. Thus, K-80003A and K-80003B are arranged about the A1/B2 pseudo-dyad, making similar but distinct interactions (Figs $1 \mathrm{~b}$ and $2 \mathrm{~b}$ ). They bind in a region where the $\mathrm{H} 12$ is located in the agonist-bound RXR $\alpha$-LBD structure (Fig. 2a) and thus distinct from the canonical ligandbinding region. The indene ring of $\mathrm{K}-80003 \mathrm{~A}$ makes many interactions with monomer $\mathrm{B} 2$, including parallel aromatic stacking with W305, and hydrophobic binding with L276 and L309, and R302. Its isopropylphenyl ring contacts K-80003C. On the other face of K-80003A, there are several hydrophobic/ aromatic interactions, including with the side-chains of F439, I447 and L451 from the A1 monomer (Fig. 2b). On the fourth side, to complete the 'cage' around $\mathrm{K}-80003 \mathrm{C}$, there are numbers of polar and ionic interactions. Notably, the carboxylate of K-80003A makes a bifurcated salt-bridge with K440 from A1 and $\mathrm{R} 302$ from B2, as well as an $\mathrm{H}$-bond with the indole $\mathrm{N}-\mathrm{H}$ of W305 (B2) (Fig. 2b). Thus, K-80003A is firmly encased on all sides at a unique location: by side-chains from $\mathrm{A} 1$ and $\mathrm{B} 2$ at the top and bottom, by molecule $\mathrm{K}-80003 \mathrm{C}$ on one side, and by elements of the invading $\mathrm{H} 11-\mathrm{H} 12$ turn and $\mathrm{H} 12$ helix on the other.

For K-80003B, the symmetry-related packing is similar but distinct with fewer interactions. The ionic interactions with R302 of $\mathrm{A} 1$ and $\mathrm{K} 440$ of $\mathrm{B} 2$ are much weaker, which may explain why $\mathrm{K}-80003 \mathrm{~B}$ is less ordered than $\mathrm{K}-80003 \mathrm{~A}$, and with less welldefined electron density. Nevertheless, it makes similar aromatic stacking interactions-in this case, parallel with F439, but a lessoptimal (45 stacking angle) with W305 (Fig. 2), as well as hydrophobic interactions with L433 of A1 and L436 of B2.

$\mathrm{K}-80003 \mathrm{C}$ binds in the pocket of monomer $\mathrm{B} 2$, in a mode that resembles a canonical ligand (Fig. 2a). Unlike K-80003A and $\mathrm{K}-80003 \mathrm{~B}$, it makes strong contacts only with the B2 subunit
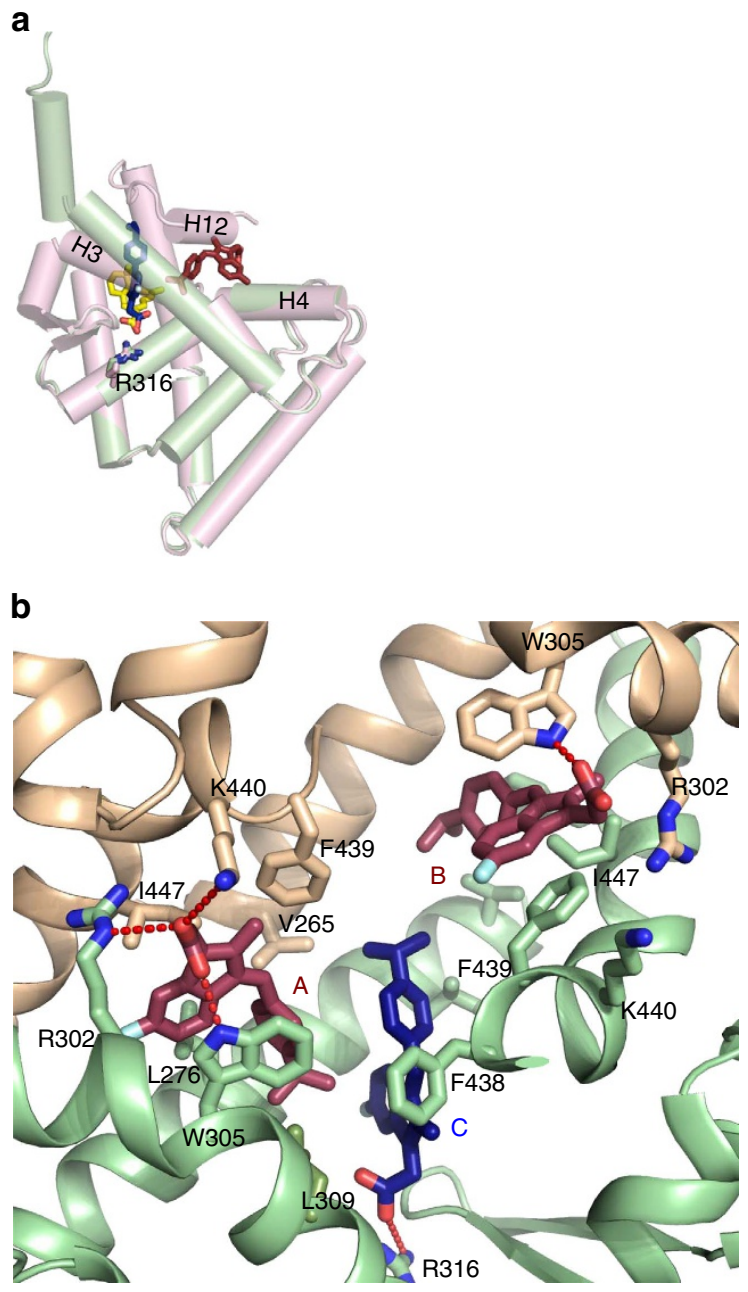

Figure 2 | Locations of the bound K-80003 molecules and their interactions with RXR $\boldsymbol{\alpha}$-LBD. (a) Superposition of a monomer subunit (green cartoon) with bound K-80003 molecules K-80003A (brown sticks) and $\mathrm{K}-80003 \mathrm{C}$ (blue/red sticks) on the agonist-binding RXR $\alpha-\mathrm{LBD}$ (magenta cartoon, PDB code 1FBY, ligand 9-cis-RA in yellow/red stick). (b) Binding of the three $\mathrm{K}-80003$ molecules (blue and brown sticks) at the interface between subunits $A 1$ and $B 2$ of the RXR $\alpha$-LBD tetramer. Selected side-chains of $R X R \alpha-L B D$ subunits that interact with the ligands are shown as sticks.

(Fig. 2b). Its carboxyl motif makes a salt-bridge with R316, while the indene ring sits in a broad hydrophobic cavity, and both are well-defined in the electron density map. However, the isopropylbenzene moiety sticks out of the pocket and into the cavity, making only weak contacts with other residues; it presumably adopts multiple conformations, consistent with the weak electron density (Supplementary Fig. 3).

Taken together, the interactions between the three bound $\mathrm{K}-80003$ molecules and the protein suggest that K-80003 stabilizes RXR $\alpha$-LBD tetramer by a unique combination of distinct and canonical-binding mechanisms acting like a '3-pronged' binding mode: $\mathrm{K}-80003 \mathrm{~A}$ is tightly packed in a hydrophobic, aromatic and polar cage that strengthens the tetramer and provides additional glue to hold $\mathrm{H} 12$ in its place to prevent coregulator binding. K-80003B also contributes to tetramer stabilization, but appears less tightly packed; significantly, however, it blocks the entrance to the unoccupied pocket in monomer A1, which might be otherwise favored by ligands such as 9-cis-RA. K-80003C binds in the pocket in monomer B2 interacting with $\mathrm{K}-80003 \mathrm{~A}$ and $\mathrm{B} 2$. 
To understand why K-80003 binds asymmetrically to the tetramer, we closely examined the shape of the tetramer's interfacial cavity. Superposition of A1/B2 subunit on to itself reveals that A1/B2 is asymmetric (Supplementary Fig. 4a) with a smaller pocket in monomer A1 than in the B2 monomer (Supplementary Fig. 4b). This asymmetry seems to be resulted from the shifts of $\mathrm{H} 3$ and $\mathrm{H} 11$ into the pocket in $\mathrm{A} 1$ (Supplementary Fig. 4c) and provides an explanation for why small molecules bind asymmetrically to the tetramer ${ }^{22,33}$. In the previously reported RXR $\alpha$-LBD/tRA-isomer tetramer structure ${ }^{22}$, tRA-isomer binds to the narrower pocket in monomer A1 where $\mathrm{K}-80003$ molecule is too big to fit in (Supplementary Fig. 4b). In our structure, the large size of the K-80003C molecule presumably selects the wider LBP pocket of the A1/B2 dimer. Despite these differences in ligand binding, the two tetramers have similar overall structures (r.m.s. deviation for $\mathrm{C} \alpha$ atoms is $1.20 \AA$ ), and the largest changes are observed at the tetramer interface (Supplementary Fig. 1b), presumably induced by the non-canonical binders, K-80003A and K-80003B.

K-80003 promotes tetramerization of tRXR $\alpha$ but not $R X R \alpha$. The unique binding of K-80003 observed in the tetrameric form of K-80003-bound RXR $\alpha$-LBD crystal structure prompted us to determine whether K-80003 binding could promote RXR $\alpha$-LBD tetramerization. In non-denaturing polyacrylamide gel electrophoresis, purified $\mathrm{RXR} \alpha-\mathrm{LBD}$ protein existed as two distinct bands corresponding to homodimer and homotetramer, respectively (Fig. 3a). As expected, incubation of RXR $\alpha$ with 9-cis-RA known to induce homodimerization ${ }^{18}$ resulted in a shift of $\mathrm{RXR} \alpha-\mathrm{LBD}$ from tetramers to dimers. In contrast, incubation with K-80003 induced an accumulation of tetramers. L433 near the $\mathrm{C}$ terminus of $\mathrm{H} 10$ packs directly against the indene ring of $\mathrm{K}-80003 \mathrm{~B}$, and its mutation to $\mathrm{D}$ would destabilize key interactions with K-80003 due to loss of existing hydrophobic interaction and introduction of repulsive chargecharge interaction with the carboxyl motif of K-80003B. Indeed, K-80003 failed to bind to RXR $\alpha-\mathrm{LBD} / \mathrm{L} 433 \mathrm{D}$ (Supplementary Fig. 5a) and promote its tetramerization (Fig. 3a). Substitution of Q275 in H3 with E, or F439 in H11 with A, which are involved in the binding of K-80003 (Fig. 2), impaired the tetramerization of respective mutants by K-80003, confirming the role of $\mathrm{H} 3$ and $\mathrm{H} 11$ in the K-80003-induced stabilization of $\mathrm{RXR} \alpha-\mathrm{LBD}$ tetramers. Interestingly, mutating $\mathrm{R} 316$ in LBP, which is essential for 9-cis-RA binding ${ }^{12}$ and involved in K-80003C binding (Fig. 2b), with E, resulted in a mutant $(\mathrm{RXR} \alpha-\mathrm{LBD} / \mathrm{R} 316 \mathrm{E})$ that exhibited mainly as a tetramer independent of the presence of either 9-cis-RA or K-80003, in agreement with a previous report ${ }^{25}$. The effect of K-80003 on stabilizing $\mathrm{RXR} \alpha$-LBD tetramers appeared overpower the 9-cisRA-induced homodimerization as RXR $\alpha$-LBD was mainly found as a tetramer in the presence of both $\mathrm{K}-80003$ and 9-cis-RA (Fig. 3a).

The ability of K- 80003 to stabilize RXR $\alpha$-LBD tetramer was also illustrated by gel filtration chromatography showing that purified $\mathrm{RXR} \alpha$-LBD protein mainly existed as a tetramer in the presence of K-80003, while it displayed predominantly as a homodimeric complex in the presence of 9-cis-RA (Fig. 3b). Evaluation of a panel of chemical crosslinkers identified homobifunctional N-hydroxysuccimide-based chemical crosslinker BS3 as the most efficient one to crosslink the RXR $\alpha$-LBD tetramer (Supplementary Fig. 5b). Thus, BS3 was subsequently used to study the effect of K-80003 on RXR $\alpha$ tetramerization. Extracts from cells transfected with RXR $\alpha$-LBD and treated with either K-80003 or 9-cis-RA were prepared and subsequently incubated with BS3. Figure $3 c$ showed that the treatment of cells with K-80003 produced crosslinked species on SDS-PAGE gels of 25,50 and $100 \mathrm{kDa}$, corresponding to monomer, dimer and tetramer of RXR $\alpha$-LBD, respectively. For comparison, treatment with 9-cis-RA resulted in only monomer and homodimer. Interestingly, $\mathrm{RXR} \alpha$ or mutants expressed in cells mainly existed as a monomer even after crosslinking, which is different from purified RXR $\alpha$ proteins. Examination of the effect of K-80003 on tetramerization of $\operatorname{tRXR} \alpha$ and $\mathrm{RXR} \alpha$ revealed that $\mathrm{K}-80003$ effectively promoted the formation of $\operatorname{tRXR} \alpha$ tetramers. Unexpectedly, K-80003 failed to promote the tetramerization of the full-length $R X R \alpha$, indicating that the $\mathrm{N}$-terminal $\mathrm{A} / \mathrm{B}$ domain interferes with its tetramerization.

The RXR $\alpha$ N/C interaction inhibits its tetramerization. The above observation prompted us to determine how the N-terminal $\mathrm{A} / \mathrm{B}$ domain of RXR $\alpha$ inhibited its tetramerization (Fig. 1). Thus, the interaction between $\mathrm{RXR} \alpha-\mathrm{A} / \mathrm{B}$ domain and $\mathrm{RXR} \alpha-\mathrm{LBD}$ (Fig. 3d) was studied by cell-based coimmunoprecipitation (coIP) assays. Immunoprecipitation of the $\mathrm{RXR} \alpha-\mathrm{A} / \mathrm{B}$ protein resulted in a strong coIP of the $\mathrm{RXR} \alpha$-LBD protein, demonstrating their interaction. The interaction was inhibited by 9-cis-RA in a dosedependent manner (Fig. 3e), and was confirmed by immunostaining showing extensive colocalization of transfected $\mathrm{RXR} \alpha-\mathrm{A} / \mathrm{B}$ with $\mathrm{RXR} \alpha-\mathrm{LBD}$ but not $\mathrm{RXR} \alpha$ in the cytoplasm of cells (Supplementary Fig. 6a). Cotransfection of the RXR $\alpha$ A/B domain completely suppressed the effect of K-80003 on promoting tRXR $\alpha$ tetramerization (Fig. 3f). These data reveal an extensive intramolecular interaction between the $\mathrm{N}$ terminus and the $\mathrm{C}$ terminus $(\mathrm{N} / \mathrm{C})$ in $\mathrm{RXR} \alpha$ and its critical role in regulating $\mathrm{RXR} \alpha$ tetramerization, and also provides a molecular explanation for the differential effect of $\mathrm{K}-80003$ on the tetramerization of $\operatorname{tRXR} \alpha$ and RXR $\alpha$.

To further study the N/C interaction, we first conducted deletion analysis of the $\mathrm{N}$-terminal $\mathrm{A} / \mathrm{B}$ region to narrow down the region required for the interaction. Deletion of either the $\mathrm{N}$-terminal 40 or 60 amino acids could not confer the ability of the resulting mutants to interact with the A/B domain (Fig. $3 \mathrm{~g}$ ). Deletion of additional 20 amino acids resulted in a mutant $(\operatorname{tRXR} \alpha)$, which strongly interacted with the $\mathrm{RXR} \alpha-\mathrm{A} / \mathrm{B}$ protein. $\operatorname{RXR} \alpha-\Delta 60$, like $\operatorname{tRXR} \alpha$, interacted strongly with $\mathrm{RAR} \gamma$ (Supplementary Fig. 6b), demonstrating that $\operatorname{RXR} \alpha-\Delta 60$ is still active in heterodimerization with $\operatorname{RAR} \gamma$. These results suggested that amino acids from 60 to 80 are critical for the N/C interaction. We next determined region in $\mathrm{RXR} \alpha-\mathrm{LBD}$ required for binding $\mathrm{A} / \mathrm{B}$ domain. $\mathrm{RXR} \alpha-\mathrm{A} / \mathrm{B}$ could interact with $\mathrm{RXR} \alpha$ mutants lacking $\mathrm{N}$-terminal sequences $(\operatorname{tRXR} \alpha, \mathrm{RXR} \alpha-\Delta 100$ and $\mathrm{RXR} \alpha-\mathrm{LBD})$ but not with mutant lacking C-terminal LBD $(\mathrm{RXR} \alpha-1-235)$ or mutants lacking $\mathrm{AF} 2 / \mathrm{H} 12$ region $(\mathrm{RXR} \alpha-$ $\Delta \mathrm{AF} 2$ and $\mathrm{RXR} \alpha-\Delta \mathrm{A} / \mathrm{B} \Delta \mathrm{AF} 2$ ) (Fig. $3 \mathrm{~h}$ ). $\mathrm{tRXR} \alpha$ without $\mathrm{AF} 2 /$ $\mathrm{H} 12$ also failed to interact with $\mathrm{RXR} \alpha-\mathrm{A} / \mathrm{B}$ (Supplementary Fig. 6c). Thus, the N/C intramolecular interaction involves the N-terminal A/B domain and the C-terminal AF2/H12. The conclusion was supported by data showing the inability of the A/B domain to bind to the full-length $\operatorname{RXR} \alpha$, likely due to the unavailability of the $\mathrm{C}$-terminal binding site masked by its own $\mathrm{N}$-terminal A/B domain. The $\mathrm{AF} 2 / \mathrm{H} 12$ is involved in the formation of the hydrophobic coactivator-binding groove that was shown to mediate the N/C interaction of some nuclear receptors ${ }^{34,35}$. To determine whether the $\mathrm{N} / \mathrm{C}$ interaction involves the coactivator-binding groove, we tested whether W305, which is located in $\mathrm{H} 5$ and was shown to play a critical role in the formation of the coactivator-binding groove ${ }^{12}$, was involved in the N/C interaction. Our results showed that RXR $\alpha-\mathrm{LBD} / \mathrm{W} 305 \mathrm{Q}$ with W305 mutated to $\mathrm{Q}$, which failed to bind to an LxxLLcontaining protein (see below), could still bind to the $\mathrm{RXR} \alpha-\mathrm{A} / \mathrm{B}$ 
protein in a 9-cis-RA sensitive manner similar to the wild-type RXR $\alpha$-LBD (Fig. 3i). These results preclude the involvement of the coactivator-binding groove in the $\mathrm{N} / \mathrm{C}$ interaction.

An LxxLL motif in p85 $\alpha$ mediates p85 $\alpha$ interaction with $R X R \alpha$. $\operatorname{tRXR} \alpha$ differs from $\operatorname{RXR} \alpha$ in its ability to reside in the cytoplasm and interact with cytoplasmic p $85 \alpha$ protein, an event that is inhibited by K-80003 (ref. 29). To address the role of tetramerization in modulating $\operatorname{tRXR} \alpha$ interaction with $\mathrm{p} 85 \alpha$, we first determined how $\mathrm{p} 85 \alpha$ binds to $\operatorname{tRXR} \alpha$. Thus, several $\mathrm{p} 85 \alpha$ mutants (Fig. 4a) were constructed and analysed for their interaction with $\operatorname{tRXR} \alpha$. CoIP experiments showed that the $\mathrm{N}$-terminal region of $\mathrm{p} 85 \alpha$, including the $\mathrm{N}$-terminal SH3 and BCR domains, is sufficient for interacting with $\operatorname{tRXR} \alpha$, whereas the C-terminal region including $\mathrm{NSH} 2$, iSH2 and $\mathrm{CSH} 2$ domains was dispensable (Fig. 4b). We further observed that a p85 $\alpha$ mutant encompassing only the BCR domain could interact with $\operatorname{tRXR} \alpha$ and $\mathrm{RXR} \alpha-\mathrm{LBD}$ but not RXR $\alpha-\mathrm{A} / \mathrm{B}$ (Fig. $4 \mathrm{c}$ ).

In an effort to understand the molecular basis for BCR interaction with $\operatorname{tRXR} \alpha$, we noticed the presence of two LxxLL motifs, ${ }^{161}$ LRQLL $^{165}$ and ${ }^{240}{ }^{\text {LQYLL }}{ }^{244}$, in BCR, which are a

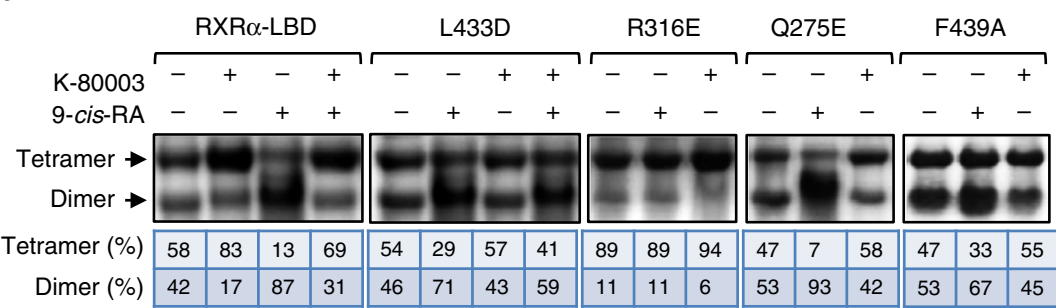

C
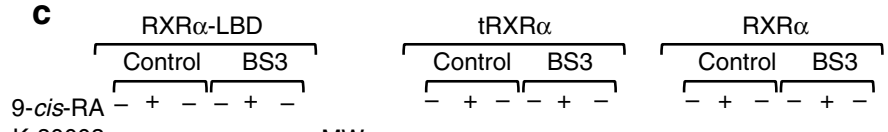

$\mathrm{K}-80003 \ldots++\ldots+\mathrm{MW}$
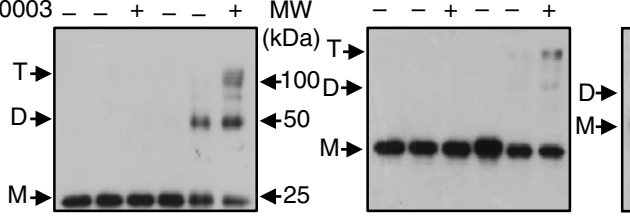

e

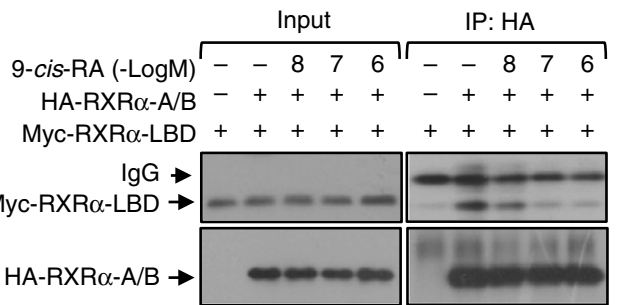

g
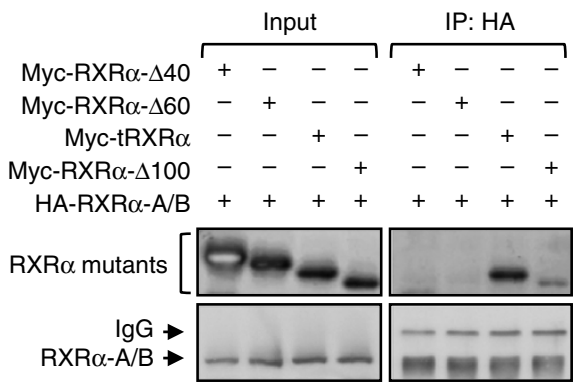

i

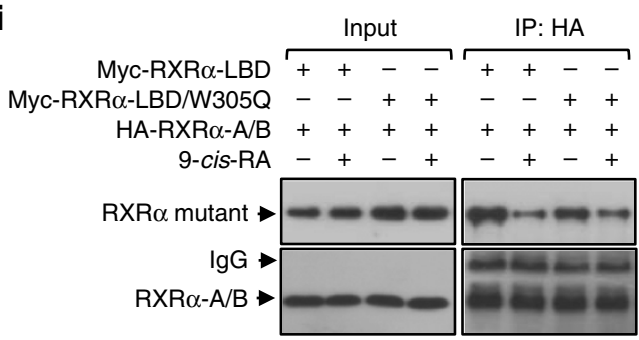

$\mathbf{f}$

h b

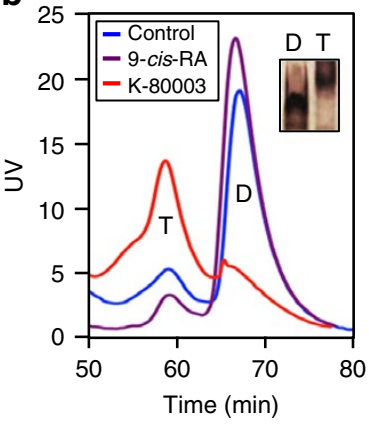

d

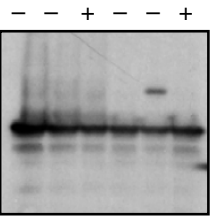

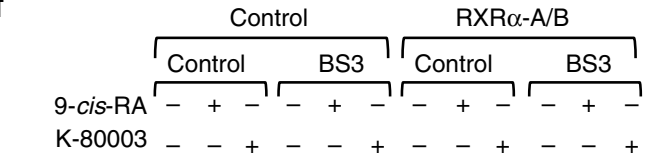
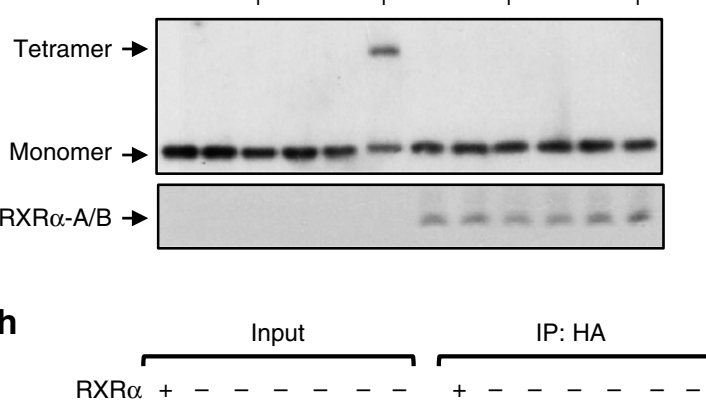

$\operatorname{tRXR} \alpha-+-\ldots-\ldots+-c_{-}-c_{-}$

$\mathrm{RXR} \alpha-\Delta 100-{ }_{-}+-c_{-}-+-{ }_{-}$

$\mathrm{RXR} \alpha-\triangle \mathrm{AF} 2-{ }_{-}+-c_{-}-c_{-}+-$

$\mathrm{RXR} \alpha-\triangle \mathrm{AB} \triangle \mathrm{AF} 2-{ }_{-}+{ }_{-}+-{ }_{-}+-$

$\mathrm{RXR} \alpha-\mathrm{LBD}-\mathrm{C}_{-}-\mathrm{C}_{-}+-\mathrm{C}_{-}$

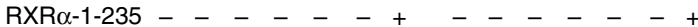

$\mathrm{RXR} \alpha-\mathrm{A} / \mathrm{B}++++++++++++++$

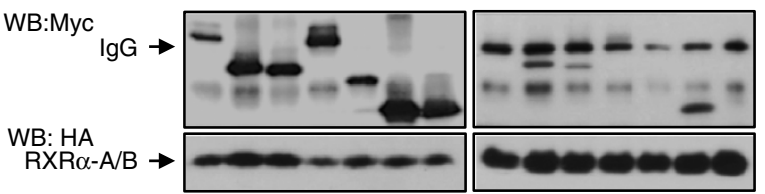


Figure 3 | Induction of RXR $\alpha$ tetramerization by $\mathbf{K}-\mathbf{8 0 0 0 3}$ and its regulation by the $\mathbf{N}-\mathbf{C}$ intramolecular interaction. (a) Equal amounts of purified $\mathrm{RXR} \alpha-\mathrm{LBD}$ or mutant protein were incubated with DMSO, 9-cis-RA, and/or K-80003, and separated by non-denaturing polyacrylamide gel electrophoresis followed by Coomassie Bright Blue staining. The percentage of tetramer and dimer of RXR $\alpha$-LBD or mutants was quantitated by densitometric analysis of the corresponding blots. One of four similar experiments is shown. (b) RXR $\alpha$-LBD incubated with K-80003 or 9-cis-RA was subject to gel filtration chromatogram assay. Results showed that 9-cis-RA-induced RXR $\alpha$-LBD was mostly in dimer (D), while K-80003-induced RXR $\alpha$-LBD was mostly in tetramer (T). One of three similar experiments is shown. (c) HepG2 cells transfected with RXR $\alpha$, tRXR $\alpha$ or RXR $\alpha$-LBD were treated with 9-cis-RA or K-80003. Cell lysates prepared were then subjected to BS3 crosslinking, and analysed by western blotting using $\Delta N 197$ anti-RXR $\alpha$ antibody. One of more than five similar experiments is shown. (d) Schematic representations of RXR $\alpha$ and mutants. $A / B, C, D, E / F$ domains in RXR $\alpha$ are indicated. (e) HepG2 cells transfected with $\mathrm{HA}-\mathrm{RXR} \alpha-\mathrm{A} / \mathrm{B}$ and Myc-RXR $\alpha-\mathrm{LBD}$ were treated with 9-cis-RA, and analysed by colP with anti-HA antibody. One of two similar experiments is shown. (f) Inhibition of K-80003-induced tRXR $\alpha$ tetramerization by A/B domain. HEK293T cells transfected with tRXR $\alpha$ together with $R X R \alpha-A / B$ were treated with $K-80003$. Cell lysates were subjected to BS3 crosslinking, and analysed by western blotting using $\triangle N 197$ anti-RXR $\alpha$ antibody. One of three similar experiments is shown. (g) RXR $\alpha-A / B$ interaction with RXR $\alpha$-terminal deletion mutants. $H A-R X R \alpha-A / B$ and $M y c-t a g g e d ~ R X R \alpha$ $\mathrm{N}$-terminal deletion mutants were transfected in to HEK293T cells, and their interaction was analysed by colP. (h) Interaction of RXR $\alpha-A / B$ with RXR $\alpha$ mutants. HA-RXR $\alpha-A / B$ and Myc-tagged RXR $\alpha$-mutants were transfected together in to HEK293T cells, and their interaction was analysed by colP. One of three similar experiments is shown. (i) Mutation of Trp305 does not affect N/C interaction. Myc-tagged RXR $\alpha$-LBD or RXR $\alpha-L B D / W 305 Q$ was transfected together with HA-RXR $\alpha-A / B$ into HEK293T cells in the presence or absence of 9-cis-RA $\left(10^{-7} \mathrm{M}\right)$. Cell lysates were prepared and analysed by colP.

commonly found in coactivators that mediates the transactivation of nuclear receptors ${ }^{10,13-16}$. Inspection of both motifs in the published BCR structure ${ }^{36}$ revealed that the ${ }^{240}$ LQYLL $^{244}$ motif is buried in the central core of the BCR domain, while the ${ }^{161}{ }^{\text {LRQLL }}{ }^{165}$ motif is located in a separate helix within a loop region. The ${ }^{161}{ }^{2 R Q L L}{ }^{165}$ motif docks well to the coactivatorbinding groove of RXR $\alpha$ (Fig. 4d), suggesting that the motif might be critical for RXR $\alpha$ binding. A peptide (BCR peptide) that encompasses the ${ }^{161}$ LRQLL $^{165}$ motif (Fig. 4a) was therefore synthesized and examined for its binding to $\mathrm{RXR} \alpha-\mathrm{LBD}$ by Biacore assay. The peptide binds strongly to RXR $\alpha$-LBD in the presence of 9 -cis-RA with a $K_{\mathrm{d}}$ of $320 \mathrm{nM}$ (Fig. 4e), which is in the range of coregulator peptide binding to nuclear receptor ${ }^{37}$. The role of the ${ }^{161}$ LRQLL $^{165}$ motif was also illustrated by the enhancing effect of 9-cis-RA on p $85 \alpha$-BCR interaction with either RXR $\alpha$-LBD or tRXR $\alpha$ (Fig. 4f). Furthermore, 9-cis-RA-induced $\mathrm{RXR} \alpha$-LBD interaction with $\mathrm{p} 85 \alpha-\mathrm{BCR}$ was inhibited by the LxxLL-containing BCR peptide conjugated with the cellpenetrating peptide derived from trans-activator of transcription (TAT), similar to the effect of K-80003, but not by the corresponding mutant peptide (Fig. 4g). Substitution of L164 and L165 in ${ }^{161}$ LRQLL $^{165}$ motif with $A$ also abolished the interaction of BCR with RXR $\alpha$-LBD (Fig. 4h). Mutating W305 critical for the formation of the coactivator-binding groove ${ }^{12}$ to $\mathrm{Q}$ impaired the binding of RXR $\alpha$-LBD with p $85 \alpha$-BCR either in the presence or absence of 9-cis-RA (Fig. 4i), even though the same mutation had no effect on RXR $\alpha$-LBD interaction with RXR $\alpha-A$ / $B$ (Fig. 3i). The interaction of the LxxLL-like motif in $\mathrm{p} 85 \alpha$ with the coactivator-binding groove of $\operatorname{tRXR} \alpha$ is biologically relevant as TNF $\alpha$-induced activation of AKT in cells transfected with $\operatorname{tRXR} \alpha$ and $\mathrm{p} 85 \alpha$ was inhibited by cotransfection of BCR but not BCR mutant, similar to the inhibitory effect of K-80003 (Supplementary Fig. 7a). Exposure of cells to BCR peptide also resulted in a similar inhibition (Supplementary Fig. 7b). Altogether, these results demonstrate that the LxxLL motif in $\mathrm{p} 85 \alpha$ can bind to the coactivator-binding groove of $\operatorname{RXR} \alpha$ in analogy to the binding of transcriptional coactivators.

Tetramerization prevents tRXR $\alpha$ from interacting with $\mathrm{p} 85 \alpha$. To further characterize the 'coactivator-like' binding of $\mathrm{p} 85 \alpha$, we studied the requirement of $\mathrm{AF} 2 / \mathrm{H} 12$ in $\operatorname{tRXR} \alpha$, which is essential for the formation of the coactivator-binding groove $\mathrm{e}^{12,38}$, for tRXR $\alpha$ interaction with $\mathrm{p} 85 \alpha$. As previously reported ${ }^{29}, \mathrm{tRXR} \alpha$ interacted with the full-length $\mathrm{p} 85 \alpha$ in the presence of TNF $\alpha$. Removing $\mathrm{AF} 2 / \mathrm{H} 12$ from $\mathrm{tRXR} \alpha(\mathrm{tRXR} \alpha / \Delta \mathrm{AF} 2)$ abolished its interaction with $\mathrm{p} 85 \alpha$ (Fig. 5a). Interfering AF2/H12 activity by transfecting $\mathrm{RXR} \alpha-\mathrm{A} / \mathrm{B}$ capable of binding AF2/H12 also inhibited 9-cis-RA-induced interaction of $\operatorname{tRXR} \alpha$ with $\mathrm{p} 85 \alpha$ $\triangle \mathrm{iSH} 2$ (Fig. 5b). These results further support the 'coactivatorlike' binding of $\mathrm{p} 85 \alpha$.

Because the coactivator-binding groove of $\operatorname{RXR} \alpha$ was shielded in the tetrameric form of $\operatorname{RXR} \alpha-\mathrm{LBD}$ (Fig. 1), our observation that the LxxLL-like motif in p85 $\alpha$ interacted with the coactivatorbinding groove of $\mathrm{RXR} \alpha$ implied that the p85 $\alpha$-binding activity of $\operatorname{tRXR} \alpha$ is impaired in its tetrameric form. To address this, we evaluated the binding of $\mathrm{p} 85 \alpha$ by two $\operatorname{tRXR} \alpha$ mutants, $\operatorname{tRXR} \alpha /$ F313A and $t R X R \alpha / R 316 \mathrm{E}$, which exist in different oligomeric forms ${ }^{25}$. RXR $\alpha / F 313 \mathrm{~A}$ is a transcriptionally constitutively active mutant receptor with $\mathrm{H} 12$ adopting an active conformation to form the coactivator-binding groove ${ }^{39}$. The mutant does not exist as a tetramer as its $\mathrm{H} 12$ is not available to contribute to the formation of tetramers ${ }^{25}$. In contrast, tRXR $\alpha / R 316 \mathrm{E}$, a transcriptionally inactive mutant, exhibited predominantly as a tetramer ${ }^{25}$. In agreement with previous observations ${ }^{25}$, our crosslink experiments detected a strong tetrameric species of $\operatorname{tRXR} \alpha /$ $\mathrm{R} 316 \mathrm{E}$ but not $\mathrm{tRXR} \alpha / \mathrm{F} 313 \mathrm{~A}$ independent of the presence of 9-cis-RA or K-80003 (Fig. 5c). When both mutants were analysed for their interaction with $\mathrm{p} 85 \alpha$ by coIP experiments, we found that $\mathrm{tRXR} \alpha / \mathrm{R} 316 \mathrm{E}$ could not bind to $\mathrm{p} 85 \alpha$ either in the absence or presence of TNF $\alpha$ or 9-cis-RA, whereas $\mathrm{tRXR} \alpha / \mathrm{F} 313 \mathrm{~A}$ showed a constitutive and 9-cis-RA-independent interaction with p $85 \alpha$ compared to tRXR $\alpha$ (Fig. 5d). K-80003 also failed to modulate the interaction of both mutants with p85 $\alpha$ (Fig. 5e). Immunostaining revealed lack of colocalization of the $\operatorname{tRXR} \alpha /$ $\mathrm{R} 316 \mathrm{E}$ mutant with $\mathrm{p} 85 \alpha$ in the absence or presence of TNF $\alpha$ (Fig. 5f). To further determine the inhibitory effect of tRXR $\alpha$ tetramerization, we examined the interaction of $\mathrm{p} 85 \alpha-\Delta \mathrm{iSH} 2$ with $\operatorname{tRXR} \alpha$ tetramers crosslinked by BS3. Cells transfected with HA-p $85 \alpha-\Delta \mathrm{iSH} 2$ and Myc-tRXR $\alpha$ were treated with 9-cis-RA and/or K-80003, and subsequently exposed to BS3. 9-cis-RAinduced $\operatorname{tRXR} \alpha$ interaction with $\mathrm{p} 85 \alpha-\Delta \mathrm{iSH} 2$ was potently inhibited by $\mathrm{BS} 3$ that stabilized $\operatorname{tRXR} \alpha$ tetramers (Fig. $5 \mathrm{~g}$ ). Furthermore, the monomeric form but not the tetrameric form of RXR $\alpha$-LBD interacted with p $85 \alpha$-BCR (Fig. 5h). These results together with our structural information demonstrate that K-80003 inhibits $\operatorname{tRXR} \alpha$ interaction with $\mathrm{p} 85 \alpha$ by promoting $\operatorname{tRXR} \alpha$ tetramerization that masks the $\mathrm{p} 85 \alpha$-binding region on $\operatorname{tRXR} \alpha$.

Tetramerization regulates $\operatorname{tRXR} \alpha$ subcellular localization. The interaction of $\operatorname{tRXR} \alpha$ with p $85 \alpha$ occurs in the cytoplasm ${ }^{29}$. We next determined whether K-80003-induced stabilization of $\operatorname{tRXR} \alpha$ tetramers could modulate its subcellular localization. When transfected into cells, both $\operatorname{tRXR} \alpha$ and $\operatorname{RXR} \alpha$ resided mainly $(>80 \%)$ in the nucleus. However, upon TNF $\alpha$ treatment 
a

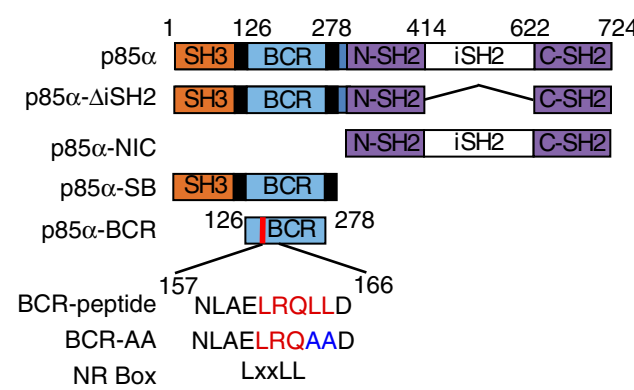

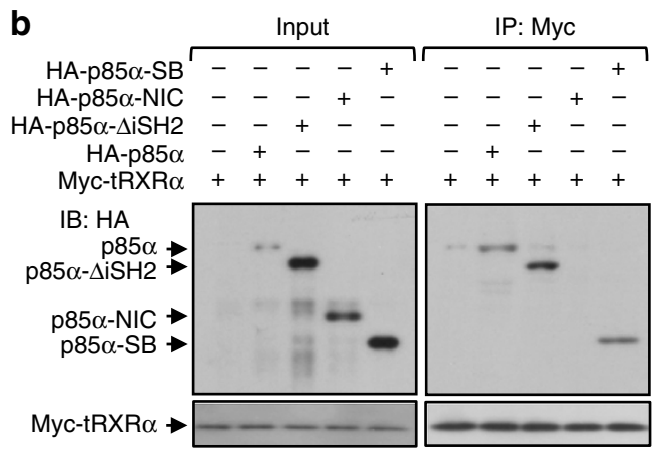

C

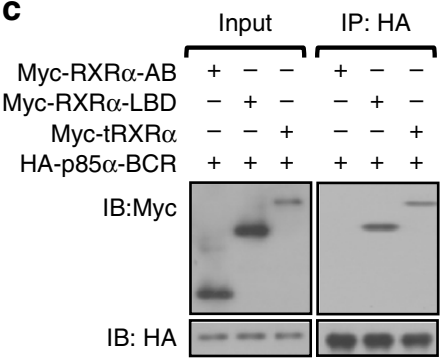

d

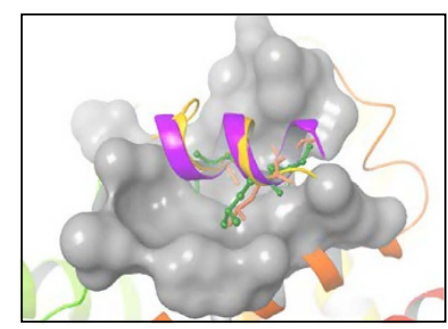

e

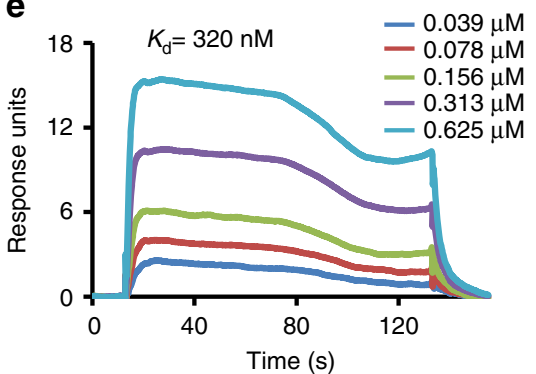

f

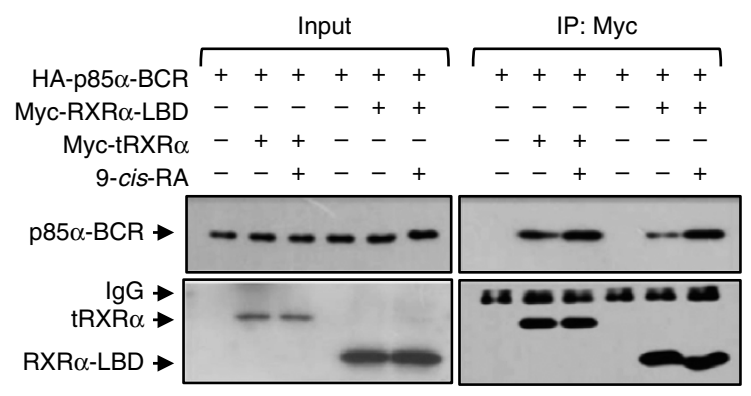

h

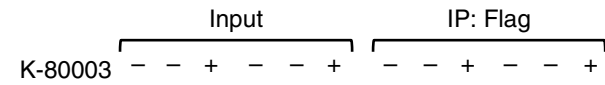

Flag-p85 $\alpha$-BCR +++---+++--

Flag-p85 $\alpha$-BCR-AA $--_{+}++-+_{+}++$

Myc-RXR $\alpha$-LBD -++-++-++-++

9-cis-RA ++++++++++++

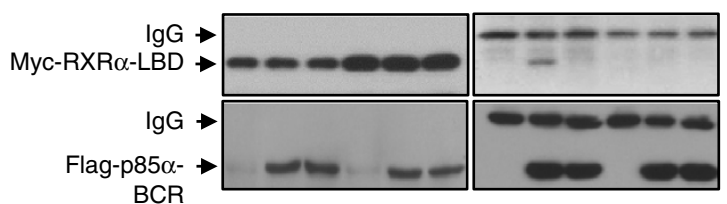

g

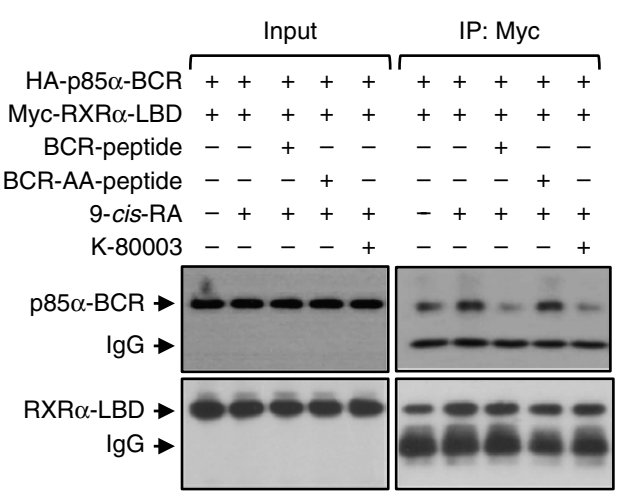

i

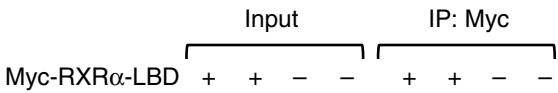

Myc-RXR $\alpha-L B D / W 305 Q-t_{-}+-t_{+}+$

$\mathrm{HA}-\mathrm{p} 85 \alpha-\mathrm{BCR}++++++++$

9-cis-RA - + - + - + +

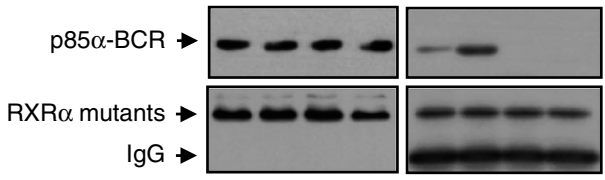

Figure 4 | Identification of an LxxLL-like motif in p85 $\alpha$ and its interaction with the coactivator-binding groove in tRXR $\alpha$. (a) Schematic representations of $\mathrm{p} 85 \alpha$ and mutants. SH3, BCR, nSH2, iSH2, CSH2 domains in p $85 \alpha$ and the location of the BCR-LxxLL motif are indicated. BCR and mutant peptides are shown. (b) Interaction of tRXR $\alpha$ with p $85 \alpha$ mutants. Myc-tRXR $\alpha$ expression vector was transfected into HEK293T cells along or together with $p 85 \alpha$ mutant tagged with HA epitope, and their interaction was analysed by colP using anti-Myc antibody. (c) BCR domain interaction with RXR $\alpha$ mutants. HA-p85 $\alpha$ BCR was cotransfected with Myc-tagged RXR $\alpha$ mutants into HEK293T cells, and their interaction was analysed by colP using anti-HA antibody. (d) The BCR-LxxLL peptide (structure was extracted from the BCR crystal structure of PDB code PBW) docks to the coactivator-binding groove on RXR $\alpha$ (PDB code 3FUG). (e) SPR analysis of BCR-peptide binding to RXR $\alpha$-LBD in the presence of 9-cis-RA. (f) Enhancing effect of 9-cis-RA on p85 $\alpha$-BCR interaction with RXR $\alpha-L B D$ and tRXR $\alpha$. Cells transfected with Myc-tRXR $\alpha$ or Myc-RXR $\alpha-L B D$ together with HA-p85 $\alpha-B C R$ were treated with 9-cis-RA (10 $\left.{ }^{-7} M\right)$, and analysed by colP. One of two similar experiments is shown. (g) Inhibitory effect of LxxLL-containing BCR peptide on RXR $\alpha$-LBD interaction with p85 $\alpha$-BCR. HEK293T cells transfected with HA-p85 $\alpha$-BCR and Myc-RXR $\alpha-L B D$ were exposed to the indicated peptide and compound for $12 \mathrm{~h}$. Cell lysates were prepared and analysed by colP. (h) Mutation of the LxxLL motif in BCR impairs its interaction with RXR $\alpha-L B D$. BCR and BCR-LxxLL mutant were tagged with Flag epitope and transfected into A549 cells with Myc-RXR $\alpha-L B D$. Cell lysates were prepared and analysed for interaction of $B C R$ and its mutant with RXR $\alpha$-LBD by colP. (i) Trp305 is essential for RXR $\alpha$-LBD binding to $p 85 \alpha-B C R$. Myc-tagged RXR $\alpha$-LBD or RXR $\alpha$-LBD/W305Q was transfected together with HA-p85 $\alpha$-BCR into HEK293T cells in the presence or absence of 9 -cis-RA $\left(10^{-7} \mathrm{M}\right)$. Cell lysates were prepared and analysed by colP. For western blotting, one of three or four similar experiments is shown. 
tRXR $\alpha$ was found in the cytoplasm of cells ( $>65 \%$ ), colocalizing extensively with $\mathrm{p} 85 \alpha$. In contrast, $\mathrm{TNF} \alpha$ had no effect on the nuclear localization of $\operatorname{RXR} \alpha$. When cells were cotreated with $\mathrm{K}-80003$, TNF $\alpha$-induced colocalization of $\operatorname{tRXR} \alpha$ with $\mathrm{p} 85 \alpha$ in the cytoplasm was inhibited, resulting in $\operatorname{tRXR} \alpha$ nuclear localization (Fig. 6a). The effect of K-80003 was likely due to its binding to $\operatorname{tRXR} \alpha$ as the cytoplasmic colocalization of $\mathrm{p} 85 \alpha$ with tRXR $\alpha / L 433 \mathrm{D}$ mutant defective in $\mathrm{K}-80003$ binding was not affected by K-80003. Thus, TNF $\alpha$-induced cytoplasmic localization of $\operatorname{tRXR} \alpha$ was likely due to its cytoplasmic
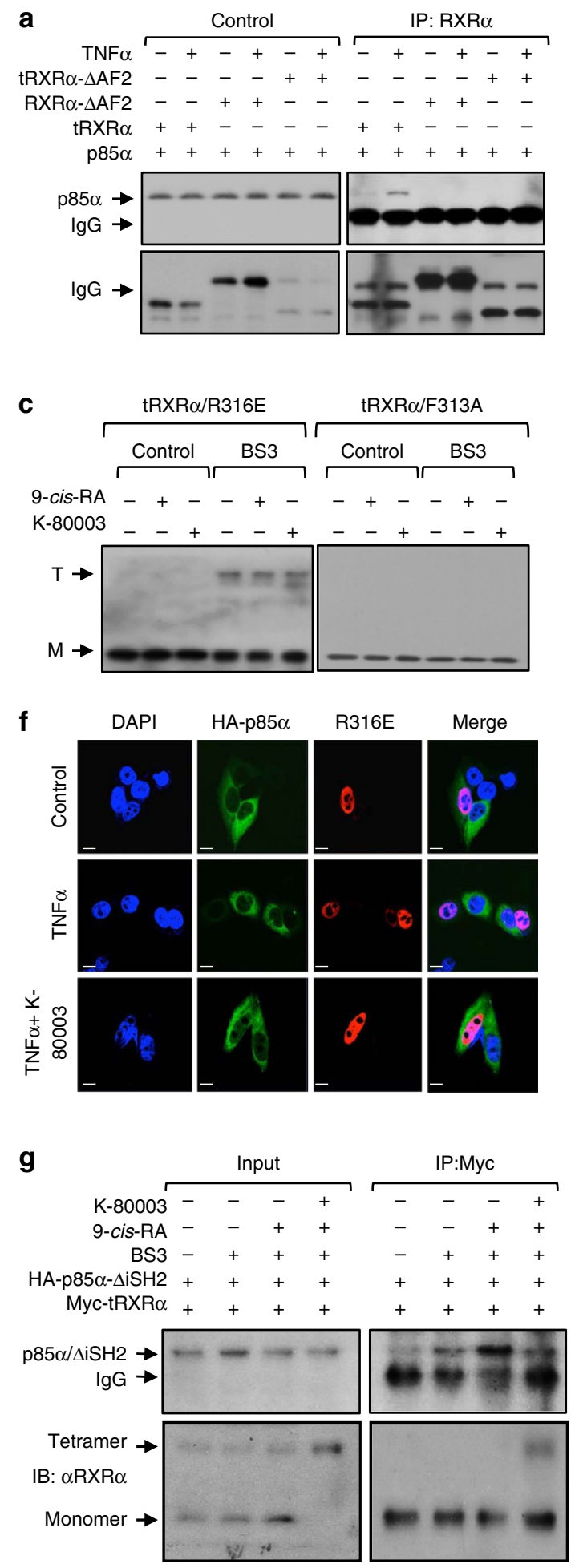

retention by $\mathrm{TNF} \alpha$-activated $\mathrm{p} 85 \alpha$ through protein/protein interaction, suggesting that $\operatorname{tRXR} \alpha$ tetramers incapable of binding $\mathrm{p} 85 \alpha$ might reside in the nucleus. To address this, extracts prepared from cells transfected with $\operatorname{tRXR} \alpha$ were subjected to crosslinking by BS3. Nuclear and cytoplasmic fractions were then prepared and analysed. Western blotting showed that K-80003-stabilized tetrameric form of $\operatorname{tRXR} \alpha$ was found exclusively in the nuclear fraction, while $\operatorname{tRXR} \alpha$ monomer was distributed both in the nuclear and cytoplasmic fractions (Fig. 6b). Thus, K-80003-stabilized $\operatorname{tRXR} \alpha$ tetramer is mainly

b

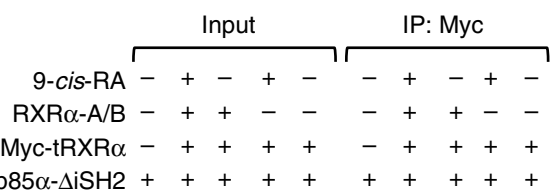

HA-p85 $\alpha-\Delta \mathrm{iSH} 2++++++++++$

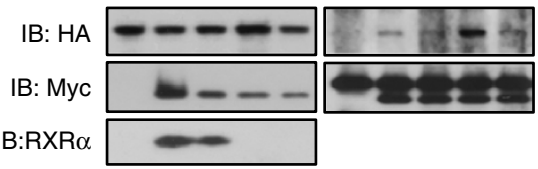

d 9-cis-RA -+--+--+-

$\mathrm{TNF} \alpha--+--+--+$

Myc-tRXR $\alpha / F 313 \mathrm{~A}-c_{-}-+++$

Myc-tRXR $\alpha / R 316 \mathrm{E}-{ }_{-}+++--$

Myc-tRXR $\alpha+++------$

HA-p85 $\alpha+++++++++$
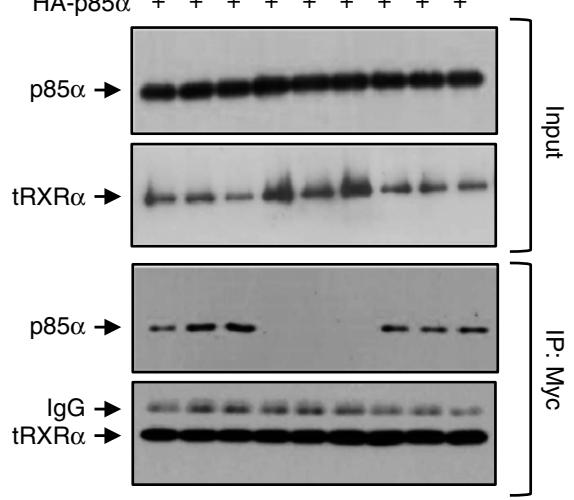

e

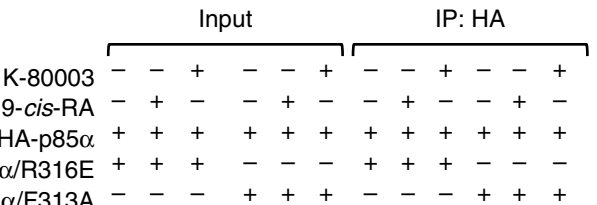

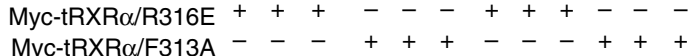

Myc-tRXRo/f313A

B: Myc

IB: HA

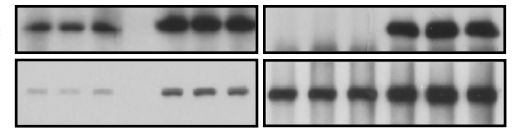

h

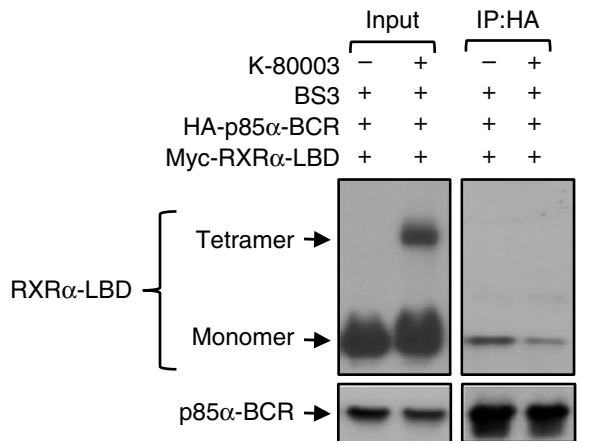


Figure 5 | Tetramerization of tRXR $\alpha$ prevents its interaction with p85 $\alpha$. (a) AF2/H12 is required for binding p85 $\alpha$. HEK293T cells transfected with HA-p85 $\alpha$ and Myc-tRXR $\alpha$ or mutants were treated with TNF $\alpha\left(10 \mathrm{ng} \mathrm{ml}^{-1}\right)$ for $1 \mathrm{~h}$, and analysed by colP assay using anti-Myc antibody. (b) Regulation of tRXR $\alpha$ interaction with $p 85 \alpha$ by ligand and RXR $\alpha-A / B$ region. HEK293T cells transfected with the indicated HA-p85 $\alpha-\Delta \mathrm{iSH} 2, \mathrm{Myc}-\mathrm{tRXR} \alpha$ and $R X R \alpha-\mathrm{A} / \mathrm{B}$ were treated with or without 9-cis-RA $\left(10^{-7} \mathrm{M}\right)$ for $6 \mathrm{~h}$, and analysed by colP assay using anti-Myc antibody. (c) Tetramerization of tRXR $\alpha / R 316 \mathrm{E}$ and tRXR $\alpha / F 313 A$ was analysed in MCF-7 cells transfected with $t R X R \alpha / R 316 E$ or $t R X R \alpha / F 313 A$, which were then treated with 9-cis-RA (10-7 M) or K-80003 $\left(5 \times 10^{-6} \mathrm{M}\right)$ for $6 \mathrm{~h}$. Cell lysates were subjected to BS3 crosslinking and analysed by western blotting using $\Delta \mathrm{N} 197$ anti-RXR $\alpha$ antibody. (d) Interaction of tRXR $\alpha / R 316 E$ and $t R X R \alpha / F 313 A$ with $p 85 \alpha$. HEK293T cells transfected with the indicated expression plasmids were treated with TNF $\alpha\left(10 \mathrm{ng} \mathrm{ml}^{-1}\right)$ or 9-cis-RA $\left(10^{-7} \mathrm{M}\right)$ for $1 \mathrm{~h}$, and analysed by colP assay using anti-Myc antibody. (e) Characterization of $\mathrm{p} 85 \alpha$ interaction with tRXR $\alpha / R 316 \mathrm{E}$ or tRXR $\alpha / F 313 A$. HEK293T cells transfected with the indicated expression plasmids were treated with 9-cis-RA $\left(10^{-7} \mathrm{M}\right)$ or $\mathrm{K}-80003\left(5 \times 10^{-6} \mathrm{M}\right)$ for $6 \mathrm{~h}$. and analysed by colP assay using anti-HA antibody. (f) Mutation of R316 impairs tRXR $\alpha$ cytoplasmic localization. HEK293T cells cotransfected with MyctRXR $\alpha /$ R316E and HA-p85 $\alpha$ were pretreated with $\mathrm{K}-80003\left(5 \times 10^{-6} \mathrm{M}\right)$ for $3 \mathrm{~h}$ before exposed to TNF $\alpha\left(10 \mathrm{ng} \mathrm{ml}^{-1}\right)$ for $30 \mathrm{~min}$. Cells were immunostained with anti-Myc and anti-p85 $\alpha$ antibody, and visualized by confocal microscopy. Scale bar, $10 \mu \mathrm{m}$. (g) Tetramerization of tRXR $\alpha$ impairs its interaction with $p 85 \alpha$. HepG2 cells transfected with Myc-tRXR $\alpha$ together with HA-p85 $\alpha-\Delta \mathrm{iSH} 2$ were treated with $\mathrm{K}-80003$ and or 9 -cis-RA. Cell lysates were then subjected to BS3 crosslinking, and analysed by western blotting using anti-Myc antibody. (h) Tetramerization of RXR $\alpha$-LBD impairs its interaction with p85 $\alpha$-BCR. HEK293T cells transfected with Myc-RXR $\alpha$-LBD together with HA-p85 $\alpha-B C R$ were treated with K-80003. Cell lysates were subjected to BS3 crosslinking, and analysed by western blotting using anti-HA antibody. For western blotting, one of three or four similar experiments is shown.

nuclear, likely resulted from $\operatorname{tRXR} \alpha$ dissociation from $\mathrm{p} 85 \alpha$ or other cytoplasmic proteins.

To study whether the anti-tumour effect of K-80003 could be attributed to its effect on the subcellular localization of $\operatorname{tRXR} \alpha$ in vivo, we stably transfected tRXR $\alpha$ or RXR $\alpha$ into MCF-7 cells, and the resulting stable clones (Supplementary Fig. 8a) were inoculated into nude mice. Overexpression of tRXR $\alpha$ but not RXR $\alpha$ in MCF-7 breast cancer cells enhanced AKT activation in vitro (Supplementary Fig. 8b) and promoted the growth of MCF-7 tumour in animals, which was suppressed when animal were treated with K-80003 (Fig. 6c; Supplementary Fig. 8c). Inhibition of the growth of MCF-7/tRXR $\alpha$ tumour by K-80003 was accompanied with reduced AKT activation and enhanced PARP cleavage (Fig. 6d). To determine whether the anti-cancer activity of $\mathrm{K}-80003$ was associated with its modulation of $\operatorname{tRXR} \alpha$ subcellular localization, tumour specimens from nude mice were analysed by $\mathrm{RXR} \alpha$ immunostaining (Fig. 6e). While RXR $\alpha$ was nuclear, $\operatorname{tRXR} \alpha$ was predominantly cytoplasmic. However, a significant amount of tRXR $\alpha$ was found in the nucleus when animals were administered with K-80003. We also used polyomavirus middle $\mathrm{T}$ antigen (PyMT) transgenic mice ${ }^{40}$ to study the anti-cancer effect of K-80003 and its modulation of the subcellular localization of tRXR $\alpha$, which was highly expressed in PyMT mammary tumour developed in these mice (Supplementary Fig. 9a). K-80003 potently inhibited the growth of PyMT mammary tumour in this animal model (Fig. 6f), accompanied with induction of PARP cleavage and inhibition of cyclin D expression (Fig. $6 \mathrm{~g}$ ) as well as inhibition of tumour cell proliferation (Supplementary Fig. 9b). Immunostaining of PyMT tumour specimens using $\Delta 197$ anti$\mathrm{RXR} \alpha$ antibody that recognizes both $\mathrm{RXR} \alpha$ and $\operatorname{tRXR} \alpha$ revealed a predominant cytoplasmic RXR $\alpha$ staining (Fig. 6h). In contrast, $\mathrm{RXR} \alpha$ staining was mainly found in the nucleus when mice were dosed with K-80003. Thus, K-80003 induction of tRXR $\alpha$ nuclear localization through its modulation of $\operatorname{tRXR} \alpha$ tetramerization likely represents a major mechanism by which the compound exerts its potent therapeutic effect.

\section{Discussion}

$\mathrm{RXR} \alpha$ is unique in that it can form not only homodimers and heterodimers but also homotetramers ${ }^{4-11,17,25,33,38}$, suggesting that the equilibrium between these different oligomeric states plays a role in regulating $\mathrm{RXR} \alpha$ functions. While the function and mechanism of RXR $\alpha$ homodimer and heterodimers are well documented, the role of RXR $\alpha$ homotetramers and its regulation remains poorly defined. We report here that K-80003 represents a unique $R X R \alpha$ ligand capable of shifting the oligomeric equilibrium by selectively binding to and stabilizing the tetrameric conformation. Our crystal structure of RXR $\alpha$-LBD in complex with K-80003 shows that six molecules of K-80003 bind in a tetramer by a unique combination of distinct and canonical binding mechanisms acting like a '3-pronged' binding mode. The comprehensive interactions between the bound K-80003 molecules and the protein provide a plausible explanation for how K-80003 binding can stabilize the tRXR $\alpha$ tetrameric state. Biochemical studies confirmed that K-80003 binding could promote tetramerization of $\operatorname{tRXR} \alpha$ but not full-length $\mathrm{RXR} \alpha$. $\mathrm{K}-80003$-induced stabilization of $\operatorname{tRXR} \alpha$ tetramer was associated with inhibition of its interaction with $\mathrm{p} 85 \alpha$ and activation of tRXR $\alpha$-dependent PI3K/AKT signalling. The tetramerization also represents a crucial event in determining the subcellular localization of tRXR $\alpha$. Collectively, these results unravel a critical role of tRXR $\alpha$ tetramerization in regulating its subcellular localization and nongenomic interaction with cytoplasmic signalling proteins.

Although how tRXR $\alpha$ binds to $\mathrm{p} 85 \alpha$ remains to be precisely defined, our data demonstrated that an LxxLL motif in p85 $\alpha$ and the amino acid residues at the coregulator-binding groove of $\operatorname{RXR} \alpha$ are critical for their interaction (Fig. 4). These data in combination with information from comparing the RXR $\alpha$-LBD dimer and $\mathrm{RXR} \alpha-\mathrm{LBD} / \mathrm{K}-80003$ tetramer crystal structures demonstrate that the potential p85 $\alpha$-binding site on tRXR $\alpha$ resides in the coregulator-binding groove. In the K-80003stabilized RXR $\alpha$-LBD tetramer, H12 protrudes into the coregulator-binding groove of the neighbouring monomer (Fig. 1), making the groove inaccessible for $\mathrm{p} 85 \alpha$ binding (Supplementary Fig. 2). Modulation of gene transcription by nuclear receptors is mediated through their interaction with coactivators or corepressors via the LxxLL motif and the L/IxxI/ VI motif, respectively ${ }^{10,13-16}$. Thus, our identification of a functional LxxLL motif in p85 $\alpha$ suggests that $\mathrm{p} 85 \alpha$ may serve as a nongenomic coregulator of tRXR $\alpha$ in analogy with the regulation of nuclear receptor transactivation by coregulators in the nucleus ${ }^{10,13-16}$. The genomic and nongenomic coregulators of $\mathrm{RXR} \alpha$ may act coordinately to mediate the crosstalk between $\mathrm{RXR} \alpha$ nuclear and cytoplasmic signallings. It is noteworthy that several nuclear receptors, including oestrogen receptor, glucocorticoid receptor, peroxisome proliferator-activated receptors, thyroid receptor and retinoic acid receptor could interact with $\mathrm{p} 85 \alpha^{41-49}$. Whether $\mathrm{p} 85 \alpha$ serves as a common coregulator for different nuclear receptors to modulate PI3K signalling remains to be seen. The concept of cytoplasmic nuclear receptor coregulators will expand our conventional view of coregulators and may lead to the identification of a class of cytoplasmic signalling proteins that mediate the nongenomic action of RXR $\alpha$ and perhaps other nuclear receptors.

Interaction between the $\mathrm{N}$ - and the C-terminal segments of a protein appears to be evolutionarily selected for some functional 
advantages ${ }^{50}$. Although the $\mathrm{N}$-terminal A/B domains of nuclear receptors are intrinsically disordered, studies have now shown that they are capable of undergoing a disorder-to-order transition upon binding specific target molecules ${ }^{3}$. Thus far, the N/C intramolecular interaction has been described for several nuclear receptors, including oestrogen receptor ${ }^{51}$, progesterone receptor $^{52}$, peroxisome proliferator-activated receptors ${ }^{53}$ and androgen receptor ${ }^{34}$. We report here that N/C interaction also occurs in $\mathrm{RXR} \alpha$ and acts to mediate $\mathrm{RXR} \alpha$ interaction with $\mathrm{p} 85 \alpha$, defining a regulatory paradigm for $\mathrm{RXR} \alpha$ action. Although how the $\mathrm{N} / \mathrm{C}$ interaction in $\mathrm{RXR} \alpha$ is mediated remains unclear, our inspection of the sequences ( ${ }^{61}$ mgppfsvisspmgphsmsvp $\left.{ }^{80}\right)$ at the $\mathrm{N}$-terminal A/B domain of $\mathrm{RXR} \alpha$ (Fig. $3 \mathrm{~g}$ ) revealed the existence of potential polyproline II (PPII) domain characterized by a PxxP core motif known to bind to SH3, WW and EVH1 domain ${ }^{54}$. This is reminiscent of previous reports that proline-rich nuclear receptor co-regulatory protein 2 (PNRC2) uses a $\mathrm{SH} 3$ domainbinding motif (SEPPSPS) to interact with the LBDs of different a
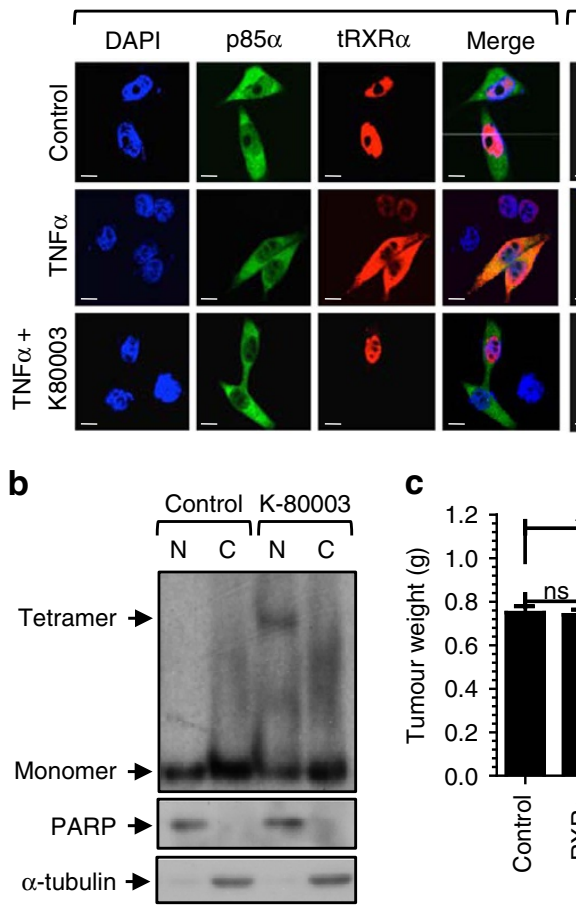

C

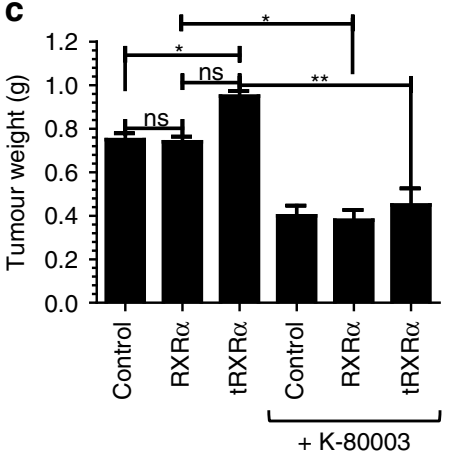

e
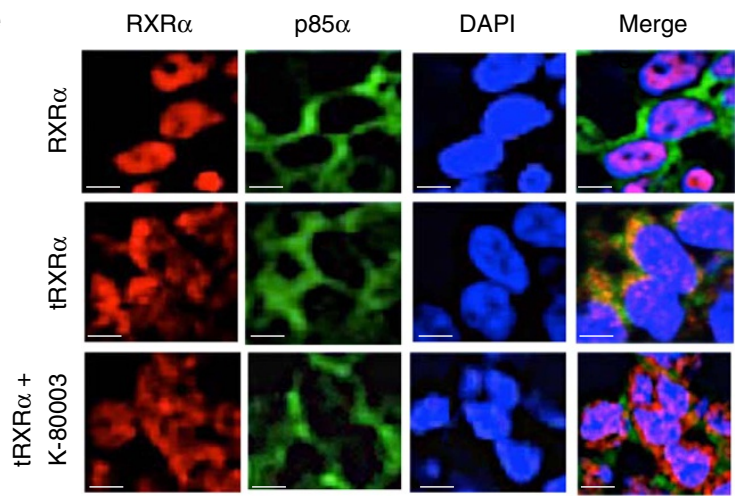

g

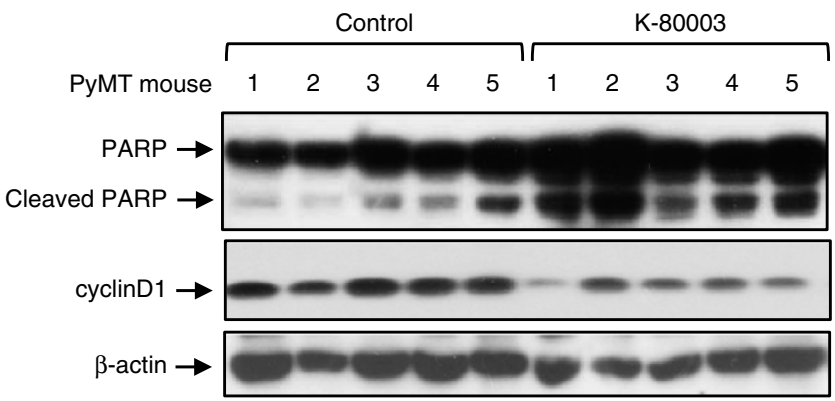

$\operatorname{RXR} \alpha$

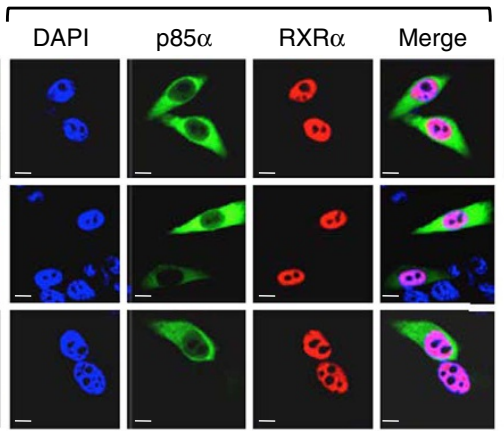

d

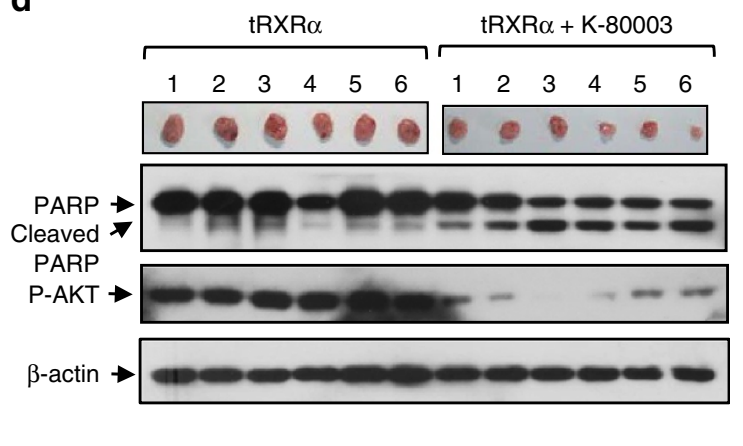

$\operatorname{tRXR} \alpha / L 433 \mathrm{D}$

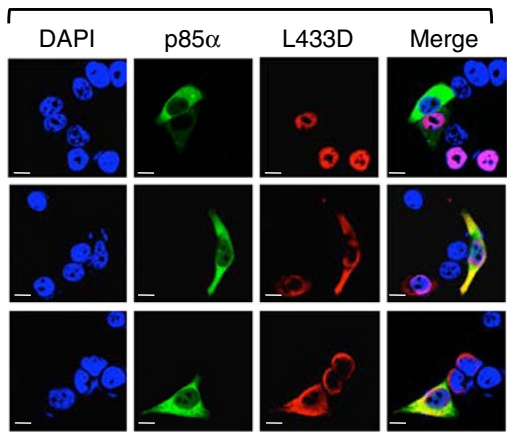


Figure 6 | Effect of tetramerization on the subcellular localization of tRXR $\alpha$. (a) Effect of TNF $\alpha$ and K-80003. MCF-7 cells cotransfected with Myc-RXR $\alpha$, Myc-tRXR $\alpha$, tRXR $\alpha / L 433 D$ and $p 85 \alpha$ were pretreated with or without $K-80003\left(5 \times 10^{-6} \mathrm{M}\right)$ for $3 \mathrm{~h}$ before exposed to TNF $\alpha\left(10 \mathrm{ng}\right.$ ml $\left.{ }^{-1}\right)$ for $30 \mathrm{~min}$. Cells were immunostained with anti-Myc and anti-p85 $\alpha$ antibody, and their subcellular localization revealed by confocal microscopy. (b) Tetrameric tRXR $\alpha$ resides in the nucleus. HEK293T cells cotransfected with Myc-tRXR $\alpha$ were treated with or without K-80003 $\left(5 \times 10^{-6} \mathrm{M}\right)$ for $6 \mathrm{~h}$. Nuclear $(\mathrm{N})$ and cytoplasmic (C) fractions were prepared, subjected to BS3 crosslinking, and analysed by western blotting using anti-Myc antibody. The purity of fractions was examined by analysing the expression of nuclear PARP and cytoplasmic $\alpha$-tubulin in non-crosslinked fractions. One of three similar experiments is shown. (c) Effect of K-80003 on the growth of MCF-7 cells in mice. Nude mice injected with MCF-7 cells stably transfected with control vector, Myc-RXR $\alpha$, or Myc-tRXR $\alpha$ were administered with $\mathrm{K}-80003\left(20 \mathrm{mg} \mathrm{kg}^{-1}\right)$ for 12 days. ${ }^{\star} P<0.05$; ${ }^{\star \star} P<0.01$. (d) Effect of K-80003 on PARP cleavage and AKT activation in MCF-7 xenograft tumours. Lysates prepared from tumours from nude mice treated with vehicle or K-80003 were analysed by western blotting. (e) K-80003 alters the subcellular localization of tRXR $\alpha$ in MCF-7 xenograft tumour cells. Tumour sections prepared from nude mice treated with vehicle or K-80003 were immunostained with anti-Myc antibody. (f) Effect of K-80003 on the growth of MMTV-PyMT mammary tumour. Four-week old MMTV-PyMT mice were fed with or without diet containing K-80003 $\left(100 \mathrm{mg} \mathrm{kg}^{-1}\right)$ for 4 weeks, and the appearance of tumour was determined. ${ }^{\star \star} P<0.01$. (g) Effect of K-80003 on PARP cleavage and cyclin D1 expression in MMTV-PyMT mammary tumour cells. Lysates prepared from tumours from MMTV-PyMT mice fed with vehicle or K-80003 were analysed by western blotting. (h) K-80003 induces RXR $\alpha$ nuclear localization in MMTV-PyMT tumour cells. Tumour sections from MMTV-PyMT mice fed with or without K-80003 $\left(100 \mathrm{mg} \mathrm{kg}^{-1}\right)$ for 4 weeks were immunostained with $\Delta$ N197 anti-RXR $\alpha$ antibody. Scale bar, $10 \mu \mathrm{m}$.

nuclear receptors including oestrogen receptor, glucocorticoid receptor, progesterone receptor, thyroid receptor, retinoic acid receptor and $\mathrm{RXR}^{55}$, and that a unique interaction motif exists in the ligand-binding domain of oestrogen receptor for binding PPII-like motif ${ }^{56}$. Although $\mathrm{AF} 2 / \mathrm{H} 12$ at the C-terminal end of $\operatorname{RXR} \alpha$ is required for the N/C interaction (Fig. 3h), the coactivator-binding groove involving the AF2/H12 was not required (Fig. 3i). This is supported by the result that the N/C interaction was inhibited by 9 -cis-RA (Fig. 3e). How the AF2/H12 engages the $\mathrm{N} / \mathrm{C}$ interaction remains to be determined. The $\mathrm{N}$-terminal $\mathrm{A} / \mathrm{B}$ domain through intramolecular interaction with the C-terminal domain may allosterically affect the function of distant domains to ensure that $\operatorname{RXR} \alpha$ activity is appropriately achieved. As the disruption of the N/C interaction has been implicated in the regulation of nuclear receptor activity, ligand sensitivity and subcellular localization $34,35,51-53$, our illustration of the existence of the N/C intramolecular interaction in $\mathrm{RXR} \alpha$ provides a molecular explanation for the oncogenic effect of tRXR $\alpha$ in tumour cells ${ }^{29}$. It is noteworthy that in addition to various proteolytically cleaved $\mathrm{RXR} \alpha$ products ${ }^{57-64}, \mathrm{RXR} \alpha$ N-terminal splicing variants have been identified ${ }^{65,66}$. Furthermore, the N-terminal A/B domain is enriched with phosphorylation sites and several kinases have been identified to phosphorylate the region ${ }^{67,68}$. $\operatorname{RXR} \alpha$ migrates from the nucleus to the cytoplasm in response to differentiation ${ }^{69}$, survival ${ }^{29,70}$, apoptosis ${ }^{71}$ and inflammation $29,70,72$. It remains to be determined if and how the N/C interaction in $\mathrm{RXR} \alpha$ plays a role in mediating the crosstalk between $\operatorname{RXR} \alpha$ and signal transduction pathways under both physiological and pathophysiological conditions.

In conclusion, our results elucidate a previously unrecognized role of $\operatorname{RXR} \alpha$ tetramers and demonstrate that conformational selection plays a critical role in the regulation of the nongenomic function of $\operatorname{RXR} \alpha$. We showed that the tetramerization of $\operatorname{RXR} \alpha$ could be regulated by several mechanisms including ligand binding, intra domain-domain interaction and nongenomic interaction with cytoplasmic signalling proteins. This study opens an opportunity to develop novel RXR $\alpha$-based therapeutics by selectively stabilizing a particular oligomeric state. The selective induction by K-80003 of the tetramerization of $\operatorname{tRXR} \alpha$ but not $\mathrm{RXR} \alpha$ suggests that this class of compounds may preferentially affect $\operatorname{tRXR} \alpha$ activity, which is therapeutically desirable since $\operatorname{tRXR} \alpha$ is often overproduced in cancer cells ${ }^{29}$.

\section{Methods}

Protein expression and purification. The human RXR $\alpha$ LBD (residues Thr223 to Thr462) cloned as an N-terminal histidine-tagged fusion protein in pET15b expression vector was expressed in Escherichia coli BL21 strain (Stratagene). After sonication, cell extract was incubated with the His60 Ni Superflow resin, and Histagged RXR $\alpha$-LBD-resin complexes were washed, eluted and concentrated to $5 \mathrm{mg} \mathrm{ml}^{-1}$ for subsequent trails $\mathrm{s}^{73,74}$. For crystallization experiment, bovine thrombin (Sigma) was used to cleave the His tag from the purified His-tagged RXR $\alpha$-LBD. The resulting His tag was removed on the Resource-Q column (GE) using $0.1-1 \mathrm{M} \mathrm{NaCl}$ gradient and the Tris-Cl pH 8 buffer. RXR $\alpha$-LDB was further purified using gel filtration on a Superdex 2002660 column (GE) pre-equilibrated with the $75 \mathrm{mM} \mathrm{NaCl}, 20 \mathrm{mM}$ Tris-Cl buffer (pH 8).

Crystallization and structure solution. Crystallization conditions were initially determined using the sitting-drop vapor-diffusion method and the crystallization screens Index and PEG-Ion solutions from Hampton Research. Final crystals were obtained by cocrystallizing the protein and the ligand. The protein-ligand complex contained $0.35 \mathrm{mM}$ of RXR $\alpha$-LBD, $0.5-0.7 \mathrm{mM}$ of a ligand, $1 \%$ DMSO, $100 \mathrm{mM}$ $\mathrm{NaCl}$ and $20 \mathrm{mM}$ Tris-Cl buffer (pH 7.6). $0.2 \mu \mathrm{l}$ of the protein-ligand complex was mixed with $0.2 \mu \mathrm{l}$ of the well solution (20\% PEG3330 and $0.2 \mathrm{M}$ Na Acetate) and incubated at $20^{\circ} \mathrm{C}$. Crystals appeared in 5-10 days and grew into $0.2 \times 0.1 \times 0.1 \mathrm{~mm}$ prisms. The crystals were flash-cooled in mother liquor containing $1.5 \mathrm{mM}$ of K-80003 and 20\% glycerol as a cryoprotectant. Diffraction data was collected from the cryo-cooled crystal $(100 \mathrm{~K})$ on an in-house diffractometer (Rigaku X-ray generator with a rotating anode, VariMax optic and R-AXIS HTC detector). Data was processed using the programme iMOSFLM, part of the CCP4 suite ${ }^{75}$. The b-factor of the data set according to the Wilson plot was $60 \AA^{2}$.

The crystal structures were determined using the molecular replacement program Phaser ${ }^{76}$ with pdb entry $4 \mathrm{~N} 8 \mathrm{R}$ as an initial model. $\operatorname{Coot}^{77}$ and the program suite Phenix ${ }^{78}$ were used for the model rebuilding and refinement. Parameter files and initial models for the ligands were prepared by eLBOW of Phenix. The data collection and refinement statistics are summarized in Table 1. Overall, $96.5 \%$ of residues in the refined structure are in favored regions of the Ramachandran plot, and no residues fall into disallowed regions. Coordinate errors, as estimated by Phenix, is $0.37(\AA)$.

Plasmid constructions. Expression plasmids Myc-RXR $\alpha$, Myc-RXR $\alpha-\Delta 40$, Myc-RXR $\alpha-\Delta 60$, Myc-tRXR $\alpha$, Myc-RXR $\alpha-\Delta 100$, Myc-RXR $\alpha-\Delta$ AF2, Myc-RXR $\alpha-$ $\Delta \mathrm{A} / \mathrm{B}, \mathrm{Myc}-\mathrm{RXR} \alpha-\Delta \mathrm{A} / \mathrm{B} \Delta \mathrm{AF} 2, \mathrm{Myc}-\mathrm{RXR} \alpha-\mathrm{LBD}, \mathrm{Myc}-\mathrm{tRXR} \alpha-\Delta \mathrm{AF} 2, \mathrm{Myc}-\mathrm{RXR} \alpha-$ 1-235, Myc-RXR $\alpha-A / B$, Myc-RXR $\alpha-L B D / W 305 Q$, Myc-tRXR $\alpha / R 316 E$, MyctRXR $\alpha / F 313 A, H A-R X R \alpha-A / B, H A-R A R \gamma$, HA-p $85 \alpha$, HA-p $85 \alpha-\Delta$ iSH2, HAp85 $\alpha$-NIC, HA-p85 $\alpha$-SH3, HA-p85 $\alpha$-BCR, Flag-p85 $\alpha$-BCR, Flag-p $85 \alpha$-BCR LxxAA mutant and bacteria expressed His-RXR $\alpha$-LBD, His-RXR $\alpha$-LBD/L433D, His-RXR $\alpha$-LBD/R316E, His-RXR $\alpha$-LBD/Q275E, His-RXR $\alpha$-LBD/F439A were constructed with standard methods (see Supplementary Table 1 for primer sequences).

Peptide synthesis. Peptides were synthesized on MBHA resin using Fmoc synthesis and DIC/HOBt coupling with an Advanced Chem Tech 350 and 396 multiple peptide synthesizer ${ }^{79}$. Cell-penetrating peptide derived from TAT (GRKKRRQRRRPPQ) was conjugated with p85 $\alpha$-peptide ${ }^{79}$. All peptides were acetylated on their $\mathrm{N}$ termini, and all were amidated on their $\mathrm{C}$ termini. Standard deprotection conditions were used for all peptides. Peptides were purified by HPLC on C18 columns and confirmed by MALDI mass analysis.

Gel filtration. Gel filtration was carried out using an AKTA FPLC system with HiLoad 16/600 Superdex $200 \mathrm{pg}$ (GE Healthcare Life) pre-equilibrated with Binding buffer ( $50 \mathrm{mM}$ Tris-Cl $(\mathrm{pH} 7.4), 200 \mathrm{mM} \mathrm{NaCl})$ at a flow rate of

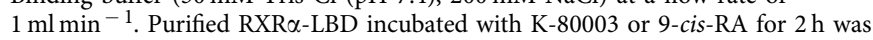


then subject to gel filtration chromatogram assay. Elutes of RXR $\alpha$-LBD protein were separated by $8 \%$ non-denaturing PAGE followed by silver staining.

Chemical crosslinking. Cells were transfected with RXR $\alpha$ or mutant expression vectors for $24 \mathrm{~h}$ and then exposed to 9-cis-RA $\left(10^{-7} \mathrm{M}\right)$ or K-80003 $\left(5 \times 10^{-6} \mathrm{M}\right)$ for $6 \mathrm{~h}$. Cell lysates were then prepared and incubated with bis[sulfosuccinimidyl] suberate (BS3, Pierce) dissolved in dimethyl sulfoxide to a final concentration of $1 \mathrm{mM}$. The reactions were stopped with protein gel loading buffer. Samples were resolved by SDS/PAGE in $8 \%$ acrylamide gels and protein bands were visualized by western blotting.

Non-denaturing gel electrophoresis. Purified RXR $\alpha$-LBD protein $\left(0.2 \mu \mathrm{g} \mu \mathrm{l}^{-1}\right)$ was incubated with DMSO, 9-cis-RA $(0.5 \mu \mathrm{M})$, and/or K-80003 $(20 \mu \mathrm{M})$ for $3 \mathrm{~h}$ at $4{ }^{\circ} \mathrm{C}$ in a total volume of $20 \mu \mathrm{l}$, and proteins were separated by $8 \%$ non-denaturing PAGE followed by Coomassie Bright Blue staining.

Cell culture and transfection. MCF-7 breast cancer cells, HepG2 liver cancer cells, A549 lung cancer cells, and HEK293T human embryonic kidney cells (from ATCC) were cultured in Dulbecco's modified Eagle's medium containing 10\% fetal bovine serum. The cells were maintained at $5 \% \mathrm{CO}_{2}$ at $37^{\circ} \mathrm{C}$. Subconfluent cells with exponential growth were used throughout the experiments. Cell transfections were carried out by using Lipofectamine 2000 (Invitrogen) according to the instructions of the manufacturer.

Compound binding. Binding of compounds to $\operatorname{RXR} \alpha-\mathrm{LBD}$ or mutant was studied in phosphate buffer at $25^{\circ} \mathrm{C}$ using isothermal titration calorimetry (ITC) assay that measures the heat either released or absorbed during binding. The purified His-tagged RXR $\alpha$-LBD or mutant protein $(50 \mu \mathrm{M}$ in $25 \mathrm{mM}$ Tris-HCl, $\mathrm{pH} 7.5$, $150 \mathrm{mM} \mathrm{NaCl}, 0.1 \%$ DMSO) was placed in the sample cell of MicroCal VP-ITC titration calorimeter. The compounds to be studied were diluted to a concentration of $1 \mathrm{mM}$ in the same buffer. All solutions were degassed before the titrations. Titration was carried out using a 2- $\mu \mathrm{l}$ compound with injection time $4 \mathrm{~s}$ and a $120 \mathrm{~s}$ delay between each injection. The heat of dilution was obtained by injecting compounds into the same buffer and subtracted from the reaction before the fitting process. Calorimetric data were analysed using MicroCal Origin software (version 7.0).

Peptide binding. Binding of BCR peptide to His-tagged RXR $\alpha$-LBD was analysed at $25^{\circ} \mathrm{C}$ by surface plasmon resonance (SPR) using a BIAcore T200 machine with CM5 chips (GE Healthcare). The purified His-tagged RXR $\alpha$-LBD protein $\left(20 \mathrm{\mu g} \mathrm{ml}^{-1}\right.$ in $10 \mathrm{mM}$ sodium acetate, $\left.\mathrm{pH} \mathrm{5}\right)$ in the presence of 9-cis-RA was immobilized on the CM5 chip via amine coupling of RXR $\alpha$-LBD's $-\mathrm{NH}_{2}$ groups according to the manufacturer's instructions. BCR peptide with different concentrations was injected into the chip. The sensor surface was regenerated with Glycine- $\mathrm{HCl}(10 \mathrm{mM}, \mathrm{pH} 2.5)$ when the data collection was finished in each cycle. Sensorgrams were fit globally with BIAcore T200 analysis using 1:1 Langmuir binding mode. The equilibrium dissociation constant $\left(K_{\mathrm{d}}\right)$ was determined using BIAcore's evaluation software provided by the manufacturer.

Western blotting. Proteins or cell lysates were electrophoresed by SDS-PAGE gel and transferred to polyvinylidene difluoride (PVDF) membrane. The membranes were blocked with $5 \%$ skimmed milk in TBST (50 mM Tris- $\mathrm{HCl}$ (pH 7.4), $150 \mathrm{mM}$ $\mathrm{NaCl}$ and $0.1 \%$ Tween 20 ) for $1 \mathrm{~h}$, then incubated with primary antibodies and secondary antibodies and detected using ECL system (Thermo). The dilutions of the primary antibodies were anti-RXR $\alpha(\Delta \mathrm{N} 197$, Santa Cruz $)$ in 1:1,000, antiPARP (H-250, Santa Cruz) in 1:3,000, anti-p85 $\alpha$ (Millipore) in 1:1,000, anti-p-AKT (D9E, Cell Signaling Technology) in 1:1000, anti-AKT1/2/3 (H-136, Santa Cruz) in 1:1,000, anti- $\beta$-actin (Sigma) in 1:5,000, anti-c-myc (9E10, Santa Cruz) in 1:3,000, anti-HA (F-7, Santa Cruz) in 1:3,000, anti-Flag (F1804, Sigma) in 1:3,000. Images of all uncropped western blots can be found in Supplementary Figs 10-14.

Coimmunoprecipitation assay. For coIP assay ${ }^{29}$, HEK293T cells grown in $10 \mathrm{~cm}$ dishes were transfected with various plasmids. Cells were lysed in $1 \mathrm{ml}$ of lysis buffer (20 mM Tris (pH 7.5), $150 \mathrm{mM} \mathrm{NaCl}, 1 \%$ Triton X-100, $1 \mathrm{mM}$ EDTA, $30 \mathrm{mM} \mathrm{NaF}$, $2 \mathrm{mM}$ sodium pyrophosphate) with a cocktail of proteinase inhibitors (Roche). Lysates were incubated with the appropriate antibody for $12 \mathrm{~h}$ at $4{ }^{\circ} \mathrm{C}$ and subsequently incubated with protein A-Sepharose beads for $1 \mathrm{~h}$. The immunoprecipitates were collected and washed three times with lysis buffer. The protein-antibody complexes recovered on beads were subjected to immunoblotting using appropriate antibodies after separation by SDS-PAGE. Input represents $5 \%$ of cell lysates used for coIP assays.

Confocal microscopy. Cells mounted on glass slides or tumour tissue frozen sections $(5-\mu \mathrm{m}$-thick) were washed with PBS and fixed in $4 \%$ paraformaldehyde (PFA) for $15 \mathrm{~min}$ and permeabilized with PBS containing $0.1 \%$ Triton X-100 for $15 \mathrm{~min}$. Fixed cells or tumour tissues were blocked with $5 \mathrm{mg} \mathrm{ml}^{-1}$ BSA in PBS for $30 \mathrm{~min}$ at room temperature, followed with incubation with primary antibodies for $3 \mathrm{~h}$ and secondary antibodies at room temperature for $1 \mathrm{~h}$ and co-stained with $4^{\prime} 6^{\prime}$-diamidino-2-phenylindole (DAPI) to visualize nuclei. The images were taken under an LSM-510 confocal laser scanning microscope system (Carl Zeiss).

Animal studies. For nude mice xenograft study, Myc-RXR $\alpha$ and Myc-tRXR $\alpha$ cloned into pcdna3.0 vector were stably transfected into MCF-7 cells, and the resulting stable clones and control clone $\left(2 \times 10^{6}\right.$ cells in $\left.100 \mu l\right)$ were injected subcutaneously into nude mice (BALB/c, SPF grade, 16-18 g, 4-5-week old). For drug treatment, mice were intraperitoneally injected (i.p.) daily with K-80003 $\left(20 \mathrm{mg} \mathrm{kg}^{-1}\right.$ ) diluted in Tween-80 or vehicle (tween-80). Body weight and tumour size were measured every 2 days. Mice were killed after 12-day drug treatment and the tumours removed for various assessments. For MMTV-PyMT transgenic mouse study, 4-week old female mice of a transgenic mouse on the FVB/N genetic background expressing the PyMT oncogene under the control of MMTV LTR promoter ${ }^{40}$ were fed with diet containing with or without K-80003 $\left(100 \mathrm{mg} \mathrm{kg}^{-1}\right)$ for 4 weeks. Estimation of tumour appearance was performed by palpation once every day. Tumour tissues of left thoracic mammary glands were excised after the treatment. Portion of tissues was used to prepare extracts for western blotting, while the rest was fixed in $4 \%$ phosphate-buffered paraformaldehyde, and used for immunohistochemical staining using anti-Ki67 antibody and immunostaining using $\Delta 197$ anti-RXR $\alpha$ antibody. All experimentations and animal usage were performed and approved by the Animal Care and Use Committee of Xiamen University.

Data analyses. Data were expressed as means \pm s.d. from three or more experiments. Statistical analysis was performed using Student's $t$-test. Differences were considered statistically significant with $P<0.05$.

Data availability. Coordinates and structure factors for the complex of RXR $\alpha$ LBD/K-80003 have been deposited in the Protein Data Bank under accession code PDB 5TBP. The rest of the data that support the conclusions of this study are available from the corresponding authors upon reasonable request.

\section{References}

1. Changeux, J. P. \& Christopoulos, A. Allosteric modulation as a unifying mechanism for receptor function and regulation. Cell 166, 1084-1102 (2016).

2. Gabizon, R. \& Friedler, A. Allosteric modulation of protein oligomerization: an emerging approach to drug design. Front. Chem. 2, 9 (2014).

3. Simons, Jr S. S., Edwards, D. P. \& Kumar, R. Minireview: dynamic structures of nuclear hormone receptors: new promises and challenges. Mol. Endocrinol. 28, 173-182 (2014)

4. Szanto, A. et al. Retinoid X receptors: X-ploring their (patho)physiological functions. Cell Death Differ. 11, S126-S143 (2004).

5. Evans, R. M. \& Mangelsdorf, D. J. Nuclear receptors, RXR, and the Big Bang. Cell 157, 255-266 (2014)

6. Lefebvre, P., Benomar, Y. \& Staels, B. Retinoid X receptors: common heterodimerization partners with distinct functions. Trends Endocrinol. Metab. 21, 676-683 (2010).

7. Su, Y. et al. Recent progress in the design and discovery of RXR modulators targeting alternate binding sites of the receptor. Curr. Top. Med. Chem. 17, 663-675 (2017).

8. Rochette-Egly, C. Retinoic acid signaling and mouse embryonic stem cell differentiation: cross talk between genomic and non-genomic effects of RA. Biochim. Biophys. Acta 1851, 66-75 (2015).

9. Gilardi, F. \& Desvergne, B. RXRs: collegial partners. Subcell. Biochem. 70, 75-102 (2014).

10. Wei, L. N. Retinoid receptors and their coregulators. Annu. Rev. Pharmacol. Toxicol. 43, 47-72 (2003).

11. Germain, P. et al. International Union of Pharmacology. LXIII. Retinoid X receptors. Pharmacol. Rev. 58, 760-772 (2006).

12. Egea, P. F. et al. Crystal structure of the human RXRa ligand-binding domain bound to its natural ligand: 9-cis-retinoic acid. EMBO J. 19, 2592-2601 (2000).

13. Hermanson, O., Glass, C. K. \& Rosenfeld, M. G. Nuclear receptor coregulators: multiple modes of modification. Trends Endocrinol. Metab. 13, 55-60 (2002).

14. Hu, X. \& Lazar, M. A. The CoRNR motif controls the recruitment of corepressors by nuclear hormone receptors. Nature 402, 93-96 (1999).

15. Lonard, D. M. \& O’Malley, B. W. Nuclear receptor coregulators: modulators of pathology and therapeutic targets. Nat. Rev. Endocrinol. 8, 598-604 (2012).

16. Privalsky, M. L. The role of corepressors in transcriptional regulation by nuclear hormone receptors. Annu. Rev. Physiol. 66, 315-360 (2004).

17. de Lera, A. R., Bourguet, W., Altucci, L. \& Gronemeyer, H. Design of selective nuclear receptor modulators: RAR and RXR as a case study. Nat. Rev. Drug Discov. 6, 811-820 (2007).

18. Zhang, X.-K. et al. Homodimer formation of retinoid X receptor induced by 9-cis retinoic acid. Nature 358, 587-591 (1992). 
19. Nunez, V. et al. Retinoid X receptor alpha controls innate inflammatory responses through the up-regulation of chemokine expression. Proc. Natl Acad. Sci. USA 107, 10626-10631 (2010).

20. Tanaka, T., Suh, K. S., Lo, A. M. \& De Luca, L. M. p21WAF1/CIP1 is a common transcriptional target of retinoid receptors: pleiotropic regulatory mechanism through retinoic acid receptor (RAR)/retinoid X receptor (RXR) heterodimer and RXR/RXR homodimer. J. Biol. Chem. 282, 29987-29997 (2007).

21. IJpenberg, A. et al. In vivo activation of PPAR target genes by RXR homodimers. EMBO J. 23, 2083-2091 (2004).

22. Gampe, Jr R. T. et al. Structural basis for autorepression of retinoid X receptor by tetramer formation and the AF-2 helix. Genes Dev. 14, 2229-2241 (2000)

23. Zhang, H. et al. Danthron functions as a retinoic $\mathrm{X}$ receptor antagonist by stabilizing tetramers of the receptor. J. Biol. Chem. 286, 1868-1875 (2011).

24. Chen, Z. P. et al. Ligand- and DNA-induced dissociation of RXR tetramers. J. Mol. Biol. 275, 55-65 (1998).

25. Kersten, S., Dong, D., Lee, W., Reczek, P. R. \& Noy, N. Auto-silencing by the retinoid X receptor. J. Mol. Biol. 284, 21-32 (1998).

26. Tice, C. M. \& Zheng, Y. J. Non-canonical modulators of nuclear receptors Bioorg. Med. Chem. Lett. 26, 4157-4164 (2016).

27. Zhang, X. K. et al. Regulation of the nongenomic actions of retinoid X receptoralpha by targeting the coregulator-binding sites. Acta Pharmacol. Sin. 36, 102-112 (2015)

28. Al Tanoury, Z., Piskunov, A. \& Rochette-Egly, C. Vitamin A and retinoid signaling: genomic and nongenomic effects. J. Lipid Res. 54, 1761-1775 (2013).

29. Zhou, H. et al. NSAID sulindac and its analog bind RXRalpha and inhibit RXRalpha-dependent AKT signaling. Cancer Cell 17, 560-573 (2010).

30. Cantley, L. C. The phosphoinositide 3-kinase pathway. Science 296, 1655-1657 (2002).

31. Zhao, L. \& Vogt, P. K. Class I PI3K in oncogenic cellular transformation. Oncogene 27, 5486-5496 (2008).

32. Bourguet, W., Ruff, M., Chambon, P., Gronemeyer, H. \& Moras, D. Crystal structure of the ligand-binding domain of the human nuclear receptor RXRalpha. Nature 375, 377-382 (1995).

33. Chen, L. et al. Sulindac-derived RXRalpha modulators inhibit cancer cell growth by binding to a novel site. Chem. Biol. 21, 596-607 (2014).

34. He, B. et al. Structural basis for androgen receptor interdomain and coactivator interactions suggests a transition in nuclear receptor activation function dominance. Mol. Cell 16, 425-438 (2004).

35. Metivier, R. et al. A dynamic structural model for estrogen receptor-alpha activation by ligands, emphasizing the role of interactions between distant A and E domains. Mol. Cell 10, 1019-1032 (2002).

36. Musacchio, A., Cantley, L. C. \& Harrison, S. C. Crystal structure of the breakpoint cluster region-homology domain from phosphoinositide 3-kinase p85 alpha subunit. Proc. Natl Acad. Sci. USA 93, 14373-14378 (1996).

37. Darimont, B. D. et al. Structure and specificity of nuclear receptor-coactivator interactions. Genes Dev. 12, 3343-3356 (1998).

38. Gampe, Jr R. T. et al. Asymmetry in the PPARgamma/RXRalpha crystal structure reveals the molecular basis of heterodimerization among nuclear receptors. Mol. Cell 5, 545-555 (2000).

39. Vivat, V. et al. A mutation mimicking ligand-induced conformational change yields a constitutive RXR that senses allosteric effects in heterodimers. EMBO J. 16, 5697-5709 (1997).

40. Guy, C. T., Cardiff, R. D. \& Muller, W. J. Induction of mammary tumors by expression of polyomavirus middle $\mathrm{T}$ oncogene: a transgenic mouse model for metastatic disease. Mol. Cell Biol. 12, 954-961 (1992).

41. Sun, M. et al. Activation of phosphatidylinositol 3-kinase/Akt pathway by androgen through interaction of p85alpha, androgen receptor, and Src. J. Biol. Chem. 278, 42992-43000 (2003).

42. Simoncini, T. et al. Interaction of oestrogen receptor with the regulatory subunit of phosphatidylinositol-3-OH kinase. Nature 407, 538-541 (2000).

43. Furuya, F., Lu, C., Guigon, C. J. \& Cheng, S. Y. Nongenomic activation of phosphatidylinositol 3-kinase signaling by thyroid hormone receptors. Steroids 74, 628-634 (2009).

44. Yan, T. D. et al. Oncogenic potential of retinoic acid receptor-gamma in hepatocellular carcinoma. Cancer Res. 70, 2285-2295 (2010).

45. Baron, S. et al. Androgen receptor mediates non-genomic activation of phosphatidylinositol 3-OH kinase in androgen-sensitive epithelial cells. J. Biol. Chem. 279, 14579-14586 (2004).

46. Furuya, F., Hanover, J. A. \& Cheng, S. Y. Activation of phosphatidylinositol 3-kinase signaling by a mutant thyroid hormone beta receptor. Proc. Natl Acad. Sci. USA 103, 1780-1785 (2006).

47. Furuya, F. et al. Ligand-bound thyroid hormone receptor contributes to reprogramming of pancreatic acinar cells into insulin-producing cells. J. Biol. Chem. 288, 16155-16166 (2013)

48. Genini, D., Garcia-Escudero, R., Carbone, G. M. \& Catapano, C. V. Transcriptional and non-transcriptional functions of PPARbeta/delta in nonsmall cell lung cancer. PLoS ONE 7, e46009 (2012).
49. Leis, H. et al. Glucocorticoid receptor counteracts tumorigenic activity of Akt in skin through interference with the phosphatidylinositol 3-kinase signaling pathway. Mol. Endocrinol. 18, 303-311 (2004).

50. Krishna, M. M. \& Englander, S. W. The N-terminal to C-terminal motif in protein folding and function. Proc. Natl Acad. Sci. USA 102, 1053-1058 (2005).

51. Metivier, R., Penot, G., Flouriot, G. \& Pakdel, F. Synergism between ERalpha transactivation function 1 (AF-1) and AF-2 mediated by steroid receptor coactivator protein-1: requirement for the AF-1 alpha-helical core and for a direct interaction between the N- and C-terminal domains. Mol. Endocrinol. 15, 1953-1970 (2001).

52. Tetel, M. J. et al. Hinge and amino-terminal sequences contribute to solution dimerization of human progesterone receptor. Mol. Endocrinol. 11, 1114-1128 (1997).

53. Shao, D. et al. Interdomain communication regulating ligand binding by PPAR-gamma. Nature 396, 377-380 (1998).

54. Zarrinpar, A., Bhattacharyya, R. P. \& Lim, W. A. The structure and function of proline recognition domains. Sci. STKE 2003, RE8 (2003).

55. Zhou, D. \& Chen, S. PNRC2 is a $16 \mathrm{kDa}$ coactivator that interacts with nuclear receptors through an SH3-binding motif. Nucleic Acids Res. 29, 3939-3948 (2001).

56. Zhou, D., Ye, J. J., Li, Y., Lui, K. \& Chen, S. The molecular basis of the interaction between the proline-rich SH3-binding motif of PNRC and estrogen receptor alpha. Nucleic Acids Res. 34, 5974-5986 (2006).

57. Casas, F. et al. Endocrine regulation of mitochondrial activity: involvement of truncated RXRalpha and c-Erb Aalphal proteins. FASEB J. 17, 426-436 (2003).

58. Matsushima-Nishiwaki, R., Shidoji, Y., Nishiwaki, S., Moriwaki, H. \& Muto, Y Limited degradation of retinoid X receptor by calpain. Biochem. Biophys. Res. Commun. 225, 946-951 (1996).

59. Matsushima-Nishiwaki, R. et al. Aberrant metabolism of retinoid X receptor proteins in human hepatocellular carcinoma. Mol. Cell Endocrinol. 121, 179190 (1996).

60. Nagaya, T. et al. Intracellular proteolytic cleavage of 9-cis-retinoic acid receptor alpha by cathepsin L-type protease is a potential mechanism for modulating thyroid hormone action. J. Biol. Chem. 273, 33166-33173 (1998).

61. Nomura, Y., Nagaya, T., Yamaguchi, S., Katunuma, N. \& Seo, H. Cleavage of RXRalpha by a lysosomal enzyme, cathepsin L-type protease. Biochem. Biophys Res. Commun. 254, 388-394 (1999).

62. Prufer, K., Schroder, C., Hegyi, K. \& Barsony, J. Degradation of RXRs influences sensitivity of rat osteosarcoma cells to the antiproliferative effects of calcitriol. Mol. Endocrinol. 16, 961-976 (2002).

63. Takiyama, Y. et al. Decreased expression of retinoid X receptor isoforms in human thyroid carcinomas. J. Clin. Endocrinol. Metab. 89, 5851-5861 (2004).

64. Zhong, C., Yang, S., Huang, J., Cohen, M. B. \& Roy-Burman, P. Aberration in the expression of the retinoid receptor, RXRalpha, in prostate cancer. Cancer Biol. Ther. 2, 179-184 (2003).

65. Brocard, J., Kastner, P. \& Chambon, P. Two novel RXR alpha isoforms from mouse testis. Biochem. Biophys. Res. Commun. 229, 211-218 (1996).

66. Kojo, H., Tajima, K., Fukagawa, M., Isogai, T. \& Nishimura, S. Molecular cloning and characterization of two novel human RXR alpha splice variants. $J$. Steroid Biochem. Mol. Biol. 92, 19-28 (2004).

67. Bruck, N. et al. Phosphorylation of the retinoid $\mathrm{x}$ receptor at the omega loop, modulates the expression of retinoic-acid-target genes with a promoter context specificity. Cell Signal. 17, 1229-1239 (2005).

68. Gianni, M., Tarrade, A., Nigro, E. A., Garattini, E. \& Rochette-Egly, C. The AF1 and AF-2 domains of RAR gamma 2 and RXR alpha cooperate for triggering the transactivation and the degradation of RAR gamma 2/RXR alpha heterodimers. J. Biol. Chem. 278, 34458-34466 (2003).

69. Katagiri, Y. et al. Modulation of retinoid signalling through NGF-induced nuclear export of NGFI-B. Nat. Cell Biol. 2, 435-440 (2000).

70. Wang, G. H. et al. Targeting truncated retinoid X receptor-alpha by CF31 induces TNF-alpha-dependent apoptosis. Cancer Res. 73, 307-318 (2013).

71. Cao, X. et al. Retinoid X receptor regulates Nur77/TR3-dependent apoptosis by modulating its nuclear export and mitochondrial targeting. Mol. Cell Biol. 24, 9705-9725 (2004).

72. Zimmerman, T. L., Thevananther, S., Ghose, R., Burns, A. R. \& Karpen, S. J. Nuclear export of retinoid X receptor alpha in response to interleukin-1betamediated cell signaling: roles for JNK and SER260. J. Biol. Chem. 281, 15434-15440 (2006).

73. Peet, D. J., Doyle, D. F., Corey, D. R. \& Mangelsdorf, D. J. Engineering novel specificities for ligand-activated transcription in the nuclear hormone receptor RXR. Chem. Biol. 5, 13-21 (1998).

74. Bourguet, W. et al. Purification, functional characterization, and crystallization of the ligand binding domain of the retinoid X receptor. Protein Expr. Purif. 6, 604-608 (1995).

75. Winn, M. D. et al. Overview of the CCP4 suite and current developments. Acta Crystallogr. D Biol. Crystallogr. 67, 235-242 (2011). 
76. McCoy, A. J. et al. Phaser crystallographic software. J. Appl. Crystallogr. 40, 658-674 (2007).

77. Emsley, P. \& Cowtan, K. Coot: model-building tools for molecular graphics. Acta Crystallogr. D Biol. Crystallogr. 60, 2126-2132 (2004).

78. Adams, P. D. et al. PHENIX: a comprehensive Python-based system for macromolecular structure solution. Acta Crystallogr. D Biol. Crystallogr. 66, 213-221 (2010)

79. Kolluri, S. K. et al. A short Nur77-derived peptide converts Bcl-2 from a protector to a killer. Cancer Cell 14, 285-298 (2008).

\section{Acknowledgements}

This study was supported by grants from the National Natural Science Foundation (91429306, 81672749, U1405229, 31271453, 31471318, 31500616, 91129302), Regiona Demonstration of Marine Economy Innovative Development Project (14PYY051SF04 and 12PYY001SF08), Fujian Provincial Science \& Technology Department (2017YZ0002), Xiamen Science and Technology Project (3502Z20123015), Ministry of Education (313050) of China, the US Army Medical Research and Material Command (W81XWH-11-1-0677), the National Institutes of Health (CA179379), and the California Breast Cancer Research Program (20IB-0138). Cell lines used were authenticated by Genetic Testing Biotechnology Corporation (Suzhou, China) using short tandem repeat (STR) markers.

\section{Author contributions}

X.-k.Z. and Y.S. designed and supervised the project, analysed data and wrote the manuscript; R.C.L. analysed structural data and wrote the manuscript; L.C., G.L., Y.Z. X.Z., X.Y. M.H., M.H., S.L., G.R., W.G., Y.M., L.C. and L.W. performed molecular and cellular experiments; A.E.A. determined the crystal structure and wrote the manuscript. Y.S., Z.C., Z.Z. and G.C. performed structural analysis; F.J., J.L. and H.Z. helped collecting and analysing biological data.

\section{Additional information}

Supplementary Information accompanies this paper at http://www.nature.com/ naturecommunications

Competing interests: The authors declare no competing financial interests.

Reprints and permission information is available online at http://npg.nature.com/ reprintsandpermissions/

How to cite this article: Chen, L. et al. Modulation of nongenomic activation of PI3K signalling by tetramerization of N-terminally-cleaved RXR $\alpha$. Nat. Commun. 8, 16066 doi: $10.1038 /$ ncomms16066 (2017).

Publisher's note: Springer Nature remains neutral with regard to jurisdictional claims in published maps and institutional affiliations.

\section{(c) (1)}

Open Access This article is licensed under a Creative Commons Attribution 4.0 International License, which permits use, sharing, adaptation, distribution and reproduction in any medium or format, as long as you give appropriate credit to the original author(s) and the source, provide a link to the Creative Commons license, and indicate if changes were made. The images or other third party material in this article are included in the article's Creative Commons license, unless indicated otherwise in a credit line to the material. If material is not included in the article's Creative Commons license and your intended use is not permitted by statutory regulation or exceeds the permitted use, you will need to obtain permission directly from the copyright holder. To view a copy of this license, visit http://creativecommons.org/ licenses/by/4.0/

(C) The Author(s) 2017 